\title{
Tonopah Test Range Air Monitoring: CY2012 Meteorological, Radiological, and Airborne Particulate Observations
}

\author{
prepared by \\ Steve A. Mizell, George Nikolich, Craig Shadel, \\ Greg McCurdy, Julianne J. Miller \\ submitted to \\ U.S. Department of Energy \\ National Nuclear Security Administration \\ Nevada Field Office
}

July 2013

Publication No. 45250 
Reference herein to any specific commercial product, process, or service by trade name, trademark, manufacturer, or otherwise, does not necessarily constitute or imply its endorsement, recommendation, or favoring by the United States Government or any agency thereof or its contractors or subcontractors.

Available for sale to the public from:

U.S. Department of Commerce

National Technical Information Service

5301 Shawnee Road

Alexandria, VA 22312

Phone: 800.553.6847

Fax: 703.605.6900

Email: orders@ntis.gov

Online ordering: http://www.osti.gov/ordering.htm

Available electronically at http://www.osti.gov/bridge

Available for a processing fee to the U.S. Department of Energy and its contractors, in paper, from:

U.S. Department of Energy

Office of Scientific and Technical Information

P.O. Box 62

Oak Ridge, TN 37831-0062

Phone: 865.576.8401

Fax: 865.576.5728

Email: reports@adonis.osti.gov 


\title{
Tonopah Test Range Air Monitoring: CY2012 Meteorological, Radiological, and Airborne Particulate Observations
}

\author{
prepared by \\ Steve A. Mizell, George Nikolich, Craig Shadel, \\ Greg McCurdy, Julianne J. Miller \\ Desert Research Institute \\ Nevada System of Higher Education
}

Publication No. 45250

submitted to

U.S. Department of Energy

National Nuclear Security Administration

Nevada Field Office

July 2013

The work upon which this report is based was supported by the U.S. Department of Energy under Contract \# DE-NA0000939. It is approved for public release: further dissemination is unlimited. 
THIS PAGE INTENTIONALLY LEFT BLANK 


\section{CONTENTS}

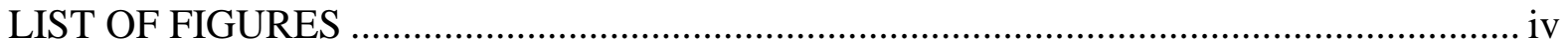

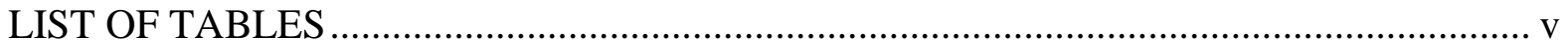

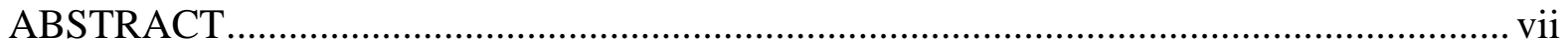

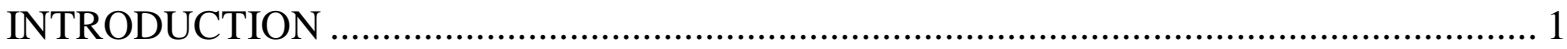

MONITORING STATIONS LOCATIONS AND CAPABILIITIES .................................. 4

RADIOLOGICAL ASSESSMENT OF AIRBORNE PARTICULATES ............................. 9

GAMMA RADIATION EXPOSURE ASSESSMENT ….............................................. 11

WEATHER CONDITIONS AND OTHER ENVIRONMENTAL PARAMETERS ............ 13

OBSERVATIONS OF SOIL TRANSPORT BY SALTATION ......................................... 20

OBSERVATIONS OF SOIL TRANSPORT BY SUSPENSION ..................................... 23

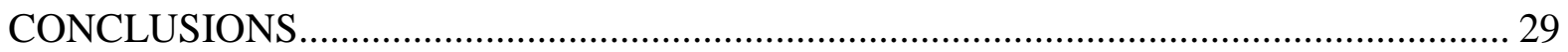

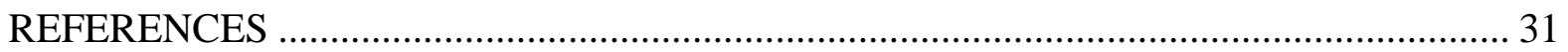

APPENDIX A: Meteorological and Environmental Data Observed at TTR Air Monitoring Stations 400, 401, and 402 during CY2012 .................................................. 32

APPENDIX B: Saltation removed from the data record prior to analysis ........................... 39 


\section{LIST OF FIGURES}

1. The Tonopah Test Range (TTR) is located at the north end of the Nevada Test and Training Range in southern Nevada................................................................................ 2

2. TTR environmental monitoring stations are located on the south side of the Sandia National Laboratory compound and the north ends of the Clean Slate 1 and 3 contamination areas.

3. Station 400 is a trailer mounted radiological and meteorological measurement system located near the Range Operations Center (ROC) in the Sandia National Laboratories compound on the Tonopah Test Range.

4. The solar powered air sampler, saltation sensor, and meteorological tower (background, center, and foreground, respectively) at Station 401 are located along the north fence that bounds the Clean Slate 3 contamination area.. 8

5. The solar powered air sampler, saltation sensor, and meteorological tower (center right, foreground left, center left, respectively) at Station 402 are located along the north fence that bounds the Clean Slate 1 contamination area.

6. Daily average gamma radiation exposure at TTR air monitoring stations 400, 401,

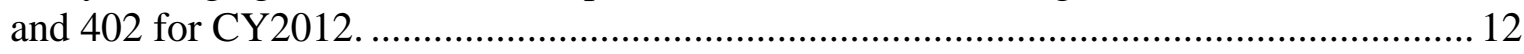

7. Ambient air temperature for Stations 400, 401, and 402 for CY2012. .............................. 14

8. Average ambient air temperature for Stations 400, 401, and 402 CY2012......................... 15

9. Average ambient soil temperature for Stations 400, 401, and 402 for CY2012................ 16

10. Comparison of average air and average soil temperatures by regression illustrates the close relationship between the two parameters at Station 401..................................... 16

11. Cumulative precipitation for Stations 400, 401, and 402 for CY2012..............................17

12. Soil volumetric water content for Stations 400, 401, and 402 for CY2012...................... 18

13. Annual wind roses for Stations 400, 401, and 402 for CY2012; left side graphics depict all winds, right side graphics depict winds greater than $24 \mathrm{~km} / \mathrm{hr}(15 \mathrm{mph})$........... 19

14. Average saltation counts increase exponentially as the wind speed increases at both TTR air monitoring Stations 401 and 402........................................................................ 22

15. Regression of $\mathrm{PM}_{10}$ concentration against saltation counts shows a strong correlation between the two measurements.

16. Wind speed frequency by wind class for Stations 400,401, and 402 for CY2012. The portion of time wind speed falls within a given class is plotted against the average wind speed for that class.

17. $\mathrm{PM}_{10}$ trends as a function of wind speed for stations 400,401 , and 402 for CY2012.......26

18. An illustrative high wind/high $\mathrm{PM}_{10}$ event observed at Station 401 on February 25 and 26, 2012. 27

19. An illustrative high wind/high $\mathrm{PM}_{10}$ event observed at Station 402 on February 25 and 26, 2012. 


\section{LIST OF TABLES}

1. Location coordinates for the TTR Air Monitoring stations.................................................. 4

2. Radiological, meteorological, and environmental sensors deployed at the TTR air monitoring stations. ................................................................................................. 6

3. Gross Alpha Results for TTR Sampling Stations 2012 …………………………............. 10

4. Gross Beta Results for TTR Sampling Stations 2012 ......................................................... 10

5. Mean annual gross alpha and gross beta concentrations for 2011 reported at CEMP stations that surround the TTR (from NSTec, 2012).......................................................... 11

6. Only naturally occurring radionuclides were identified by gamma spectroscopy analysis of the CY2012 particulate samples........................................................................ 11

7. Average daily and total annual gamma radiation exposure at TTR air monitoring stations 400, 401, and 402 during CY2012. ...................................................................... 13

8. Average daily and annual gamma radiation exposure values for 2011 reported at CEMP stations that surround the TTR (from NSTec, 2012)............................................. 13

9. Average saltation particle counts by wind speed class at TTR air monitoring Stations 401 and 402 .

10. Summary of wind and PM10 data for Stations 400, 401, and 402 for calendar year 2012.

\section{LIST OF ACRONYMS}

CAU

CEMP

CS I

CS III

DOE

GOES

NNSA/NFO

NNSS

NTTR

PIC

ROC

RSL

SNL

TDR

TTR

WRCC
Corrective Action Unit

Community Environmental Monitoring Program

Clean Slate I

Clean Slate 3

Department of Energy

Geostationary Operational Environmental Satellite

National Nuclear Security Administration, Nevada Field Office

Nevada National Security Site

Nevada Test and Training Range

Pressurized ion chamber

Range Operations Center

Radiological Services Laboratory

Sandia National Laboratories

Time Domain Reflectometry

Tonopah Test Range

Western Regional Climate Center 
THIS PAGE INTENTIONALLY LEFT BLANK 


\section{ABSTRACT}

In 1963, the Atomic Energy Commission (AEC), predecessor to the US Department of Energy (DOE), implemented Operation Roller Coaster on the Tonopah Test Range (TTR) and an adjacent area of the Nevada Test and Training Range (NTTR) (formerly the Nellis Air Force Range (NAFR)). Operation Roller Coaster consisted of four tests in which chemical explosions were detonated in the presence of nuclear devices to assess the dispersal of radionuclides and evaluate the effectiveness of storage structures to contain the ejected radionuclides. These tests resulted in dispersal of plutonium over the ground surface downwind of the test ground zero. Three tests, Clean Slate 1, 2, and 3, were conducted on the TTR in Cactus Flat; the fourth, Double Tracks, was conducted in Stonewall Flat on the NTTR.

DOE is working to clean up and close all four sites. Substantial cleaned up has been accomplished at Double Tracks and Clean Slate 1. Cleanup of Clean Slate 2 and 3 is on the DOE planning horizon for some time in the next several years.

The Desert Research Institute installed two monitoring stations, number 400 at the Sandia National Laboratories Range Operations Center and number 401 at Clean Slate 3, in 2008 and a third monitoring station, number 402 at Clean Slate 1, in 2011 to measure radiological, meteorological, and dust conditions. The primary objectives of the data collection and analysis effort are to (1) monitor the concentration of radiological parameters in dust particles suspended in air, (2) determine whether winds are re-distributing radionuclides or contaminated soil material, (3) evaluate the controlling meteorological conditions if wind transport is occurring, and (4) measure ancillary radiological, meteorological, and environmental parameters that might provide insight to the above assessments.

The following observations are based on data collected during CY2012.

The mean annual concentration of gross alpha and gross beta is highest at Station 400 and lowest at Station 401. This difference may be the result of using filter media at Station 400 with a smaller pore size than the media used at the other two stations.

Average annual gamma exposure at Station 401 is slightly greater than at Station 400 and 402. Average annual gamma exposure at all three TTR stations are in the upper range to slightly higher than values reported for the CEMP stations surrounding the TTR.

At higher wind speeds, the saltation counts are greater at Station 401 than at Station 402 while the suspended particulate concentrations are greater at Station 402 than at Statin 401. Although these observations seem counterintuitive, they are likely the result of differences in the soil material present at the two sites. Station 401 is located on an interfluve elevated above two adjacent drainage channels where the soil surface is likely to be composed of coarser material. Station 402 is located in finer sediments at the playa edge and is also subject to dust from a dirt road only $500 \mathrm{~m}$ to the north. 
During prolonged high wind events, suspended dust concentrations at Station 401 peaked with the initial winds then decreased whereas dust concentrations at Station 402 peaked with each peak in the wind speed. This likely reflects a limited $\mathrm{PM}_{10}$ source that is quickly expended at Station 401 relative to an abundant $\mathrm{PM}_{10}$ source at Station 402.

In CY2013, to facilitate comparisons between radiological analyses of collected dust, the filter media at all three stations will be standardized. In addition, a sequence of samples will be collected at Station 400 using both types of filter media to enable development of a mathematical relationship between the results derived from the two filter types. Additionally, having acquired approximately four years of observations at Stations 400 and 401 and a year of observations at Station 402, a period-of-record analysis of the radiological and airborne dust conditions will be undertaken. 


\section{INTRODUCTION}

In May and June 1963 the U.S. Department of Energy (DOE) (the Atomic Energy Commission at the time) implemented Operation Roller Coaster to evaluate the dispersal of radionuclides when nuclear devices were subjected to chemical explosions while in storage or transit (Dick and others, 1963; Johnson and Edwards, 1996). The Operation consisted of four tests, Double Tracks conducted in Stonewall Flat on the Nevada Test and Training Range (NTTR) and Clean Slate 1, 2, and 3 conducted in Cactus Flat on the Tonopah Test Range (TTR); both test areas are southeast of Tonopah, Nye County, Nevada (Figures 1 and 2).

Double Tracks was designed to assess plutonium release with minimum entrainment whereas the Clean Slate tests were intended to evaluated weapons storage scenarios. As a result, the Clean Slate tests involved one weapon containing plutonium and several simulated weapons containing uranium (Dick and others, 1963; Johnson and Edwards, 1996). For each test, data collection was distributed along arcs within a quarter-circle wedge shaped area emanating from the test ground-zero (GZ) and centered on a radius extending from GZ to the south or southeast (Dick and others, 1963; Johnson and Edwards, 1996), the expected downwind directions.

Post-shot cleanup at each test involved disposal of contaminated debris in a pit at ground-zero, scraping the surface soil around GZ to a depth of several inches and placing it in the disposal pit or mounding it over the contaminated debris. The mound of contaminated materials was covered with additional soil and compacted and watered (Johnson and Edwards, 1996). Based on soil survey data collected using a hand-held meter, the GZ disposal area was fenced to demarcate the area exhibiting plutonium concentrations greater than or equal to $1,000 \mu \mathrm{g} / \mathrm{m}^{2}$. In 1973, following another soil survey, a second fence was constructed at the approximate limit of $40 \mathrm{pCi} / \mathrm{g}$ of plutonium (Duncan and others, 2000).

Aerial surveys of Roller Coaster contamination areas were conducted in 1977 (EG\&G, 1979) and 1993 (Proctor and Hendricks, 1995). These surveys used gamma detectors to identify americium which, as a daughter product, is a readily measured indicator of plutonium. Based on the 1977 survey, the total area of diffuse plutonium for all Roller Coaster sites was estimated to be $20 \times 10^{-6} \mathrm{~m}^{2}$ (4942.11 acres). The 1993 survey estimated the maximum concentration at the Clean Slate 1 ground zero (GZ) to be between 200 and $400 \mathrm{pCi} / \mathrm{g}$. At Clean Slate 2 and 3, the maximum concentrations, again at GZ, were reported to be in excess of $2000 \mathrm{pCi} / \mathrm{g}$. Contamination was reported outside of the outer perimeter fence at all three Clean Slate sites. At Clean Slate 3, plutonium detections outside of the fence did not exceed $200 \mathrm{pCi} / \mathrm{g}$; however, at Clean Slate 1 and 2 the concentrations reported outside the fence were in excess of $200 \mathrm{pCi} / \mathrm{g}$ but less than $400 \mathrm{pCi} / \mathrm{g}$ (Proctor and Hendricks, 1995).

After soil remediation reduced the concentration of transuranics to less than or equal to 200 pCi/g, Double Tracks was closed in 1996 (Duncan and others, 2000). Soil contamination at Clean Slate 1 was remediated in 1997 so that the concentration of transuranics was less than or equal to $400 \mathrm{pCi} / \mathrm{g}$ (SNL, 2012). Clean Slate 2 and 3 have not been remediated. 


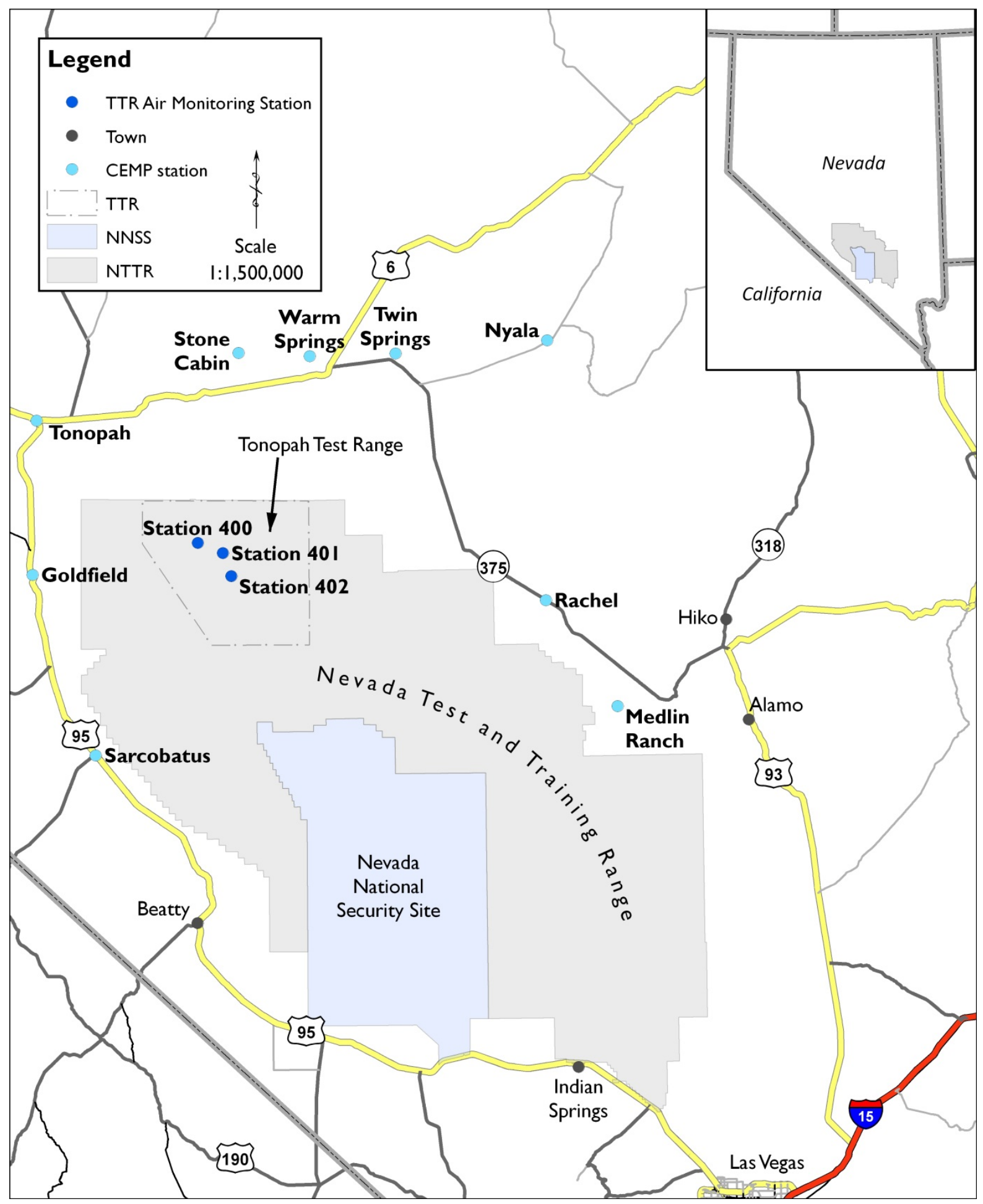

Figure 1. The Tonopah Test Range (TTR) is located at the north end of the Nevada Test and Training Range in southern Nevada. 


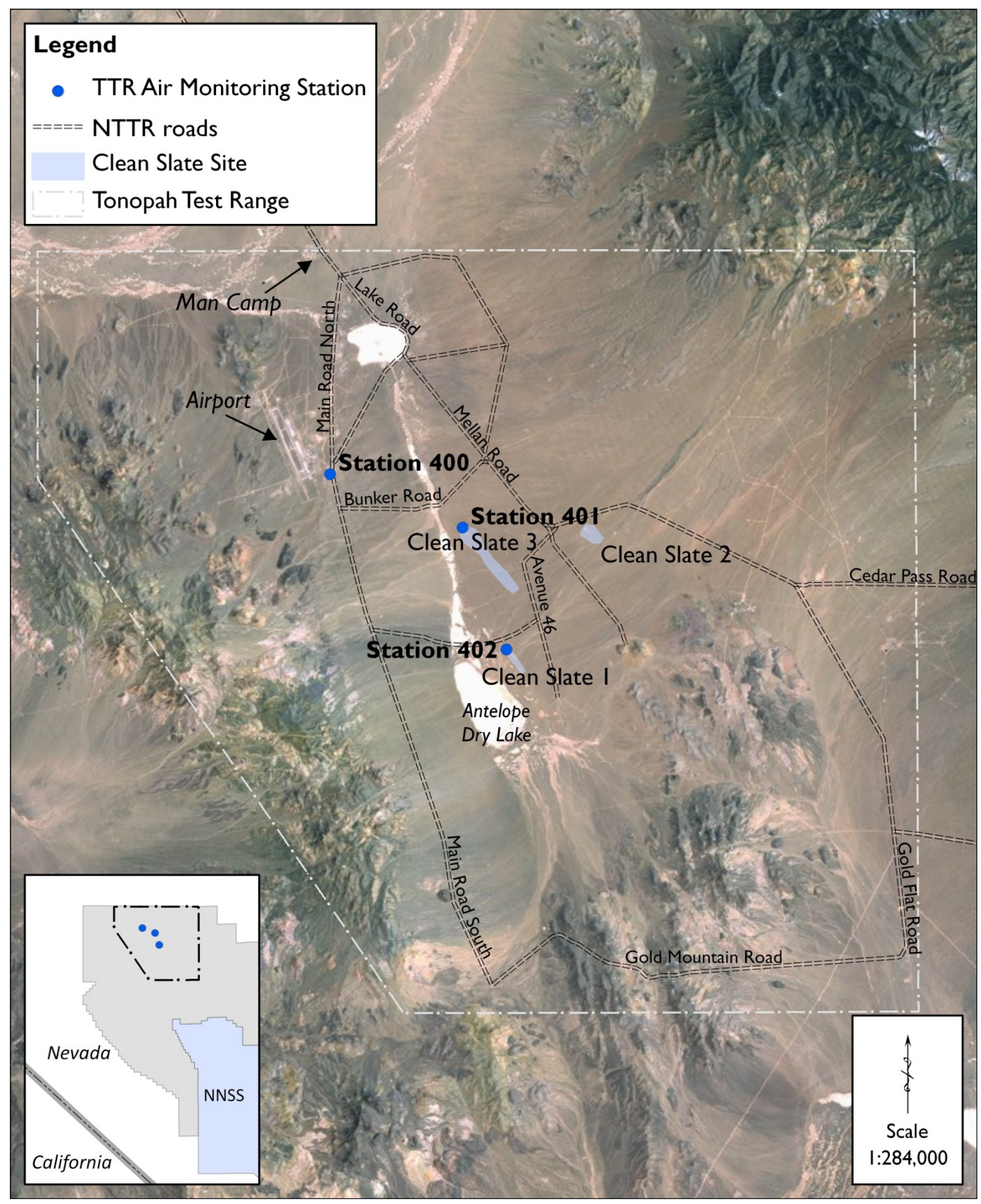

Figure 2. TTR environmental monitoring stations are located on the south side of the Sandia National Laboratory compound and the north ends of the Clean Slate 1 and 3 contamination areas. 
In 2008, at the request of the Department of Energy (DOE), National Nuclear Security Administration, Nevada Field Office (NNSA/NFO), the Desert Research Institute (DRI) constructed and deployed two portable environmental monitoring stations at the Tonopah Test Range (TTR) as part of the Environmental Management Operations Soils Activity. A third station was deployed in 2011. The DRI has operated these stations continuously since installation. The primary objective of the monitoring stations is to evaluate whether there is wind transport of radiological contaminants from Soils Corrective Action Units (CAUs) associated with Operation Roller Coaster, and if so, under what conditions it occurs.

\section{MONITORING STATIONS LOCATIONS AND CAPABILIITIES}

As part of its work under the Soils Activity, DRI operates three portable monitoring stations at TTR. Stations 400 and 401 were installed in May and June 2008, respectively. Station 402 was installed in May 2011. The monitoring stations were installed to facilitate assessment of wind transport of plutonium from the surficial soil contamination sites resulting from the Clean Slate tests. Wind direction, access, and power availability were key considerations in selection of specific monitoring station locations. Wind data for the Tonopah Airport (Engelbrecht and others, 2008) indicated that the predominant wind directions in the area were from the northwest and south-southeast. Wind direction data collected from the TTR monitoring stations substantiate the assessment of Engelbrecht and others (2008).

Station 400 was located at the Sandia National laboratories (SNL) Range Operations Center (ROC). Station coordinates are given in Table 1. The ROC, adjacent TTR airfield, and surrounding work area are downwind of the Clean Slate contamination sites when winds are out of the south-southeast. At a distance of 8 to 9 kilometers (5 to 6 miles), these facilities are the closest, regularly manned work locations to the Clean Slate contamination sites. Thus, Station 400 facilitates characterization of radiological conditions in the TTR work areas that may result from wind transport of contaminated soils at the Clean Slate sites and provides data to compare radiological conditions at the ROC with conditions at the Clean Slate sites. Station 400 was originally located just north of the center of the SNL compound approximately 145 m west-northwest of the ROC. In 2012, the station was moved about 200 $\mathrm{m}$ to the southeast at the request of SNL. In the new location, Station 400 is approximately $90 \mathrm{~m}$ (300 yd) south of the ROC near the southeast corner of the SNL compound (Figure 2). SNL provides line power to operate the equipment at Station 400 which consists of a meteorological tower and air sampling equipment installed on a $2.1 \mathrm{~m} \mathrm{x} 4.3 \mathrm{~m}$ (7 ft x $14 \mathrm{ft}$ ) trailer (Figure 3).

Stations 401 and 402 are located at the demarcation fence on the northwest perimeter of the Clean Slate 3 and Clean Slate 1 sites, respectively (Figure 2). These locations were chosen because they place the monitoring instrumentation in proximity to the contamination sites and on the downwind side of the sites during south-southeast winds, one of the two predominate wind directions through the area. Both Stations 401 and 402 are solar powered with battery backup power; the batteries are recharged continuously by solar panels. Table 1 gives the coordinates for these monitoring stations. At Stations 401 and 402 the air samplers and solar panels and batteries used to power them are on trailers. This arrangement requires 
Table 1. Location coordinates for the TTR Air Monitoring stations

\begin{tabular}{ccc}
\hline Station & Latitude & Longitude \\
\hline Station 400 - original & $37^{\circ} 47^{\prime} 15^{\prime \prime} \mathrm{N}$ & $116^{\circ} 45^{\prime} 26^{\prime}$ W \\
- current & $37^{\circ} 47^{\prime} 10^{\prime \prime} \mathrm{N}$ & $116^{\circ} 45^{\prime} 21^{\prime}$ W \\
Station 401 - air sampler & $37^{\circ} 45^{\prime} 39^{\prime} \mathrm{N}$ & $116^{\circ} 40^{\prime} 58^{\prime} \mathrm{W}$ \\
- meteorological tower & $37^{\circ} 45^{\prime} 41^{\prime} \mathrm{N}$ & $116^{\circ} 40^{\prime} 59^{\prime} \mathrm{W}$ \\
Station 402 & $37^{\circ} 42^{\prime} 33^{\prime} \mathrm{N}$ & $116^{\circ} 39^{\prime} 32^{\prime} \mathrm{W}$ \\
\hline
\end{tabular}

that the meteorological towers be installed on free-standing tripods separate from the trailer (Figures 4 and 5).

The fundamental design of these stations is similar to that used in the Community Environmental Monitoring Program (CEMP) (NSTec, 2012); equipment deployed provides data on radiological, meteorological, and environmental conditions. Table 2 lists the parameters measured and approximate date of initial data collection at each of the three monitoring stations.

Plutonium was the principal radionuclide released into the environment during the Clean Slate experiments. It attaches to small soil particles and is likely to be suspended in the air and transported from the site along with windblown dust. Additionally, americium, a daughter product of plutonium that releases gamma energy during decay, is much easier to detect than the alpha particle released during plutonium decay. Therefore, two radiological data collection systems are deployed at each of the monitoring stations. A Pressurized Ionization Chamber (PIC) measures gamma exposure and airborne particulates are collected for radiological analysis. Continuous flow, low volume air samplers (flow rate is approximately $0.05663 \mathrm{~m}^{3}\left[2 \mathrm{ft}^{3}\right.$ ] per minute) are used to collect airborne particulates. Glass fiber filters (pore size: $0.3 \mu \mathrm{m}$ ) are used at Station 400 and cellulose fiber filters (pore size: 20 to $25 \mu \mathrm{m}$ ) are used at Stations 401 and 402; all filters are $10 \mathrm{~cm}$ (4 inch) diameter. Filters are retrieved every two weeks and are delivered to the Radiological Services Laboratory (RSL) at the University of Nevada, Las Vegas for analyses. Standard analyses include gross alpha/beta measurements and gamma spectral analysis. Samples may undergo alpha spectral analysis if initial gamma spectral analyses indicate the presence of Americium-241 (Am241), which could suggest that plutonium particles are being transported.

Inhalation of airborne plutonium particles is the exposure path most likely to result in health effects in humans. Because plutonium particles tend to attach to small soil particles suspension of contaminated dust is the most likely mechanism for human exposure as well as for transport beyond the known extent of contamination. Suspension and transport of contaminated dust is controlled by local meteorological and other environmental conditions, such as, wind speed and soil moisture content. Many meteorological parameters influence these conditions. Electronic sensors generally measure meteorological and other environmental conditions every 3 seconds; these measurements are averaged or totaled, as 
appropriate, and stored in the on-site data logger every 10 minutes. The data loggers are downloaded during site visits every two weeks. But to facilitate assessment of instrument performance and to provide rapid updates of observations, daily averages of the 10-minute data are transmitted to the Western Regional Climate Center (WRCC) via the Geostationary Operational Environmental Satellite (GOES) system. At the WRCC data are quality checked and archived for analysis.

In addition to the automatic sensors, at Station 400 two MiniVols ${ }^{\mathrm{TM}}$ (Air Metrics, Eugene, Oregon) are deployed. These samplers are intended to be run in the event of a nearby wildfire or during extreme dust storms because they are set up to facilitate analyses that distinguish organic and inorganic constituents. The MiniVols ${ }^{\mathrm{TM}}$ are manually activated low-volume air samplers equipped with Teflon filter media. No events caused the MiniVols to be activated in 2012, so no data were collected from these instruments.

Table 2. Radiological, meteorological, and environmental sensors deployed at the TTR air monitoring stations.

\begin{tabular}{lccc}
\hline \multicolumn{1}{c}{ Instrument/Measurement } & Station 400 & Station 401 & Station 402 \\
\hline Wind speed & $5 / 27 / 2008$ & $6 / 10 / 2008$ & $5 / 18 / 2011$ \\
Wind direction & $5 / 27 / 2008$ & $12 / 22 / 2009$ & $5 / 18 / 2011$ \\
Precipitation & $5 / 27 / 2008$ & $12 / 22 / 2009$ & $5 / 18 / 2011$ \\
Temperature & $5 / 27 / 2008$ & $6 / 10 / 2008$ & $5 / 18 / 2011$ \\
Relative humidity & $5 / 27 / 2008$ & $6 / 10 / 2008$ & $5 / 18 / 2011$ \\
Solar radiation & $5 / 27 / 2008$ & na & $5 / 18 / 2011$ \\
Barometric pressure & $5 / 27 / 2008$ & na & $5 / 18 / 2011$ \\
Soil temperature & $5 / 27 / 2008$ & $12 / 22 / 2009$ & $5 / 18 / 2011$ \\
Soil moisture content & $5 / 27 / 2008$ & $12 / 22 / 2009$ & $5 / 18 / 2011$ \\
Airborne particle size profiler & $5 / 27 / 2008$ & $6 / 10 / 2008$ & $5 / 18 / 2011$ \\
Airborne particle collector & $5 / 27 / 2008$ & $7 / 30 / 2008$ & $8 / 23 / 2011$ \\
Saltation senor & na & $8 / \mathrm{x} / 2011$ & $8 / \mathrm{x} / 2011$ \\
Gamma radiation PIC & $5 / 27 / 2008$ & $12 / 22 / 2009$ & $12 / 15 / 2011$ \\
Data logger & $5 / 27 / 2008$ & $6 / 10 / 2008$ & $5 / 18 / 2011$ \\
GOES transmitter & $5 / 27 / 2008$ & $12 / 22 / 2009$ & $5 / 18 / 2011$ \\
\hline & & & \\
\hline & 5 & & \\
\hline
\end{tabular}




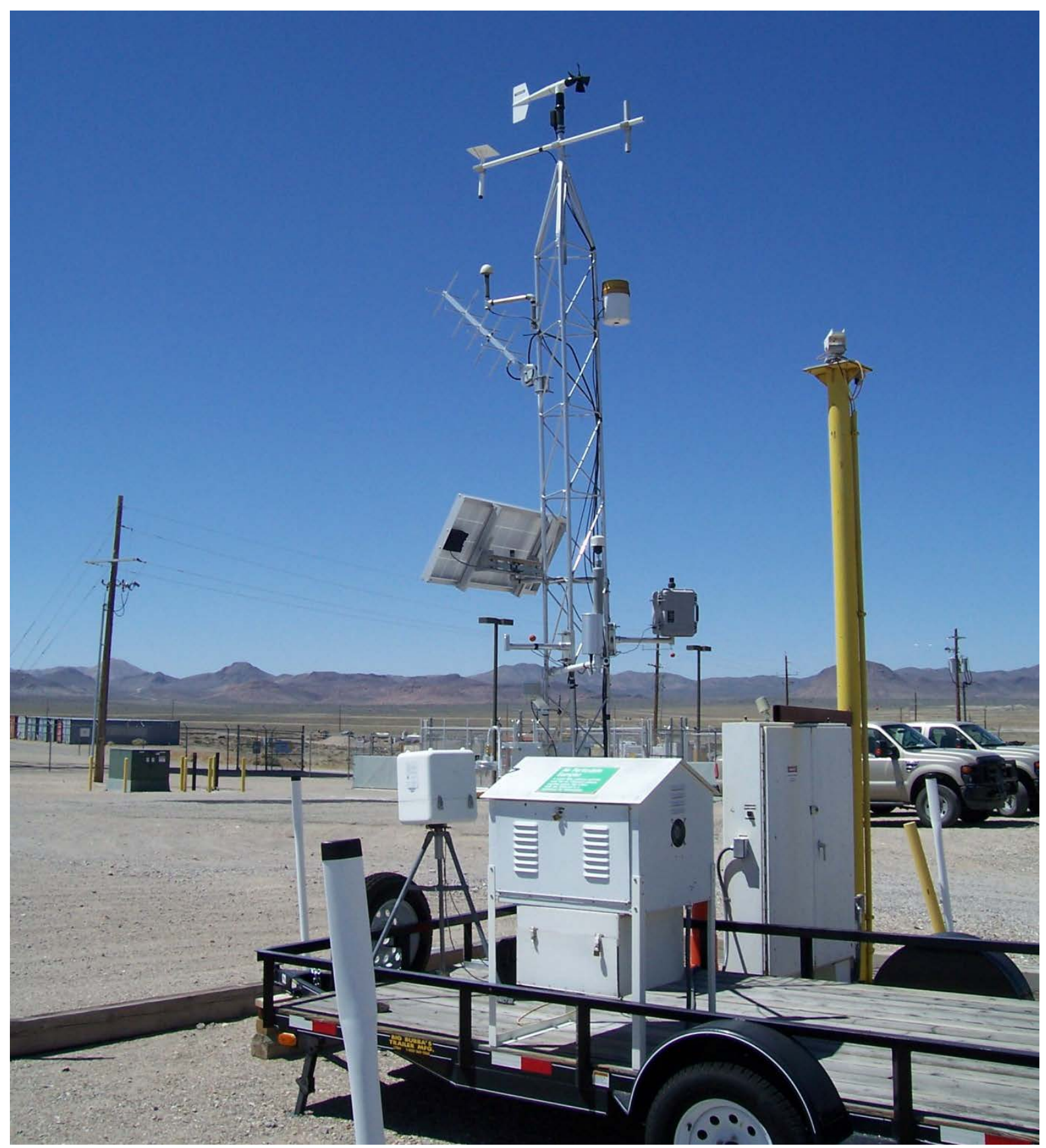

Figure 3. Station 400 is a trailer mounted radiological and meteorological measurement system located near the Range Operations Center (ROC) in the Sandia National Laboratories compound on the Tonopah Test Range. 


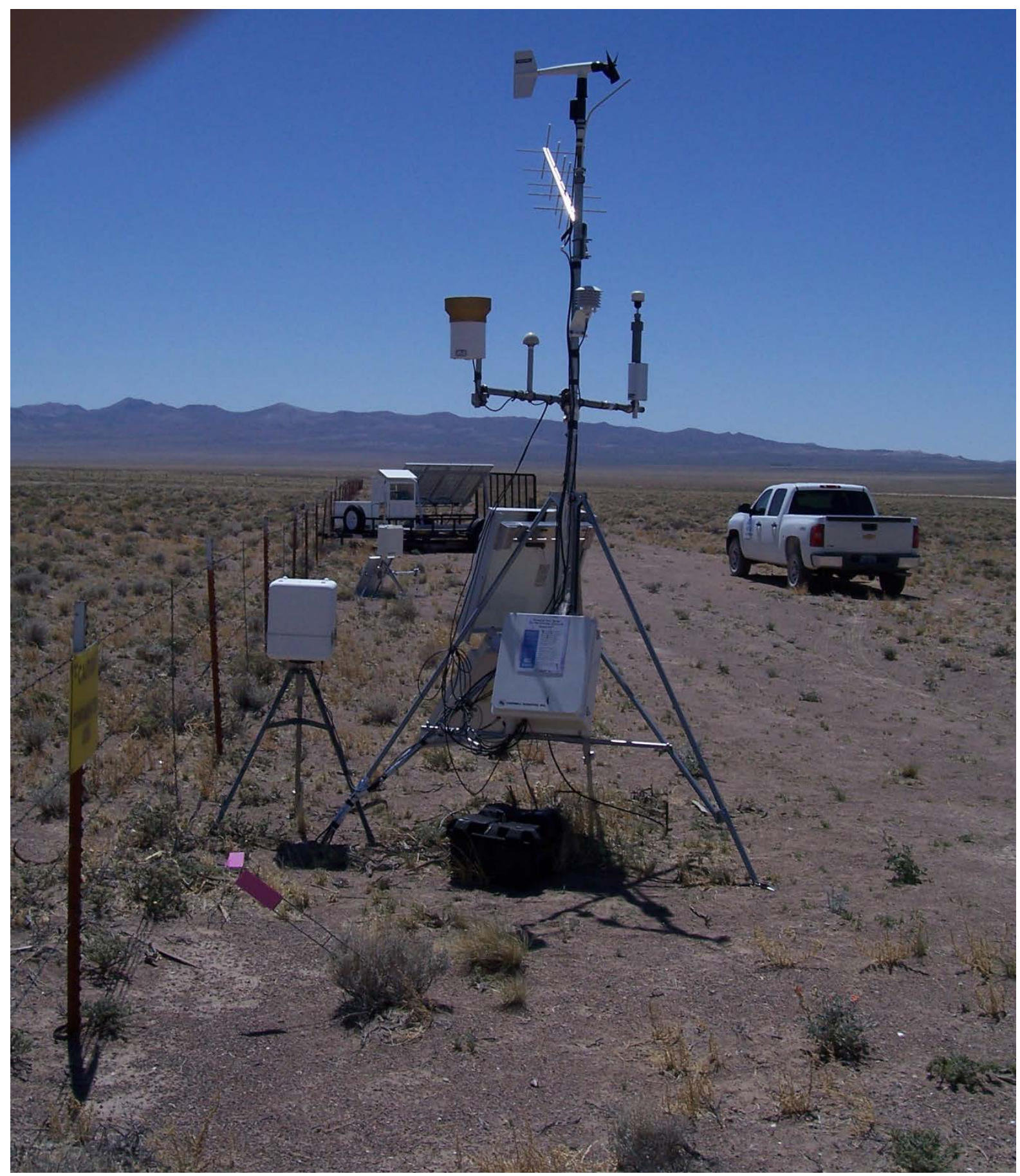

Figure 4. The solar powered air sampler, saltation sensor, and meteorological tower (background, center, and foreground, respectively) at Station 401 are located along the north fence that bounds the Clean Slate 3 contamination area. 


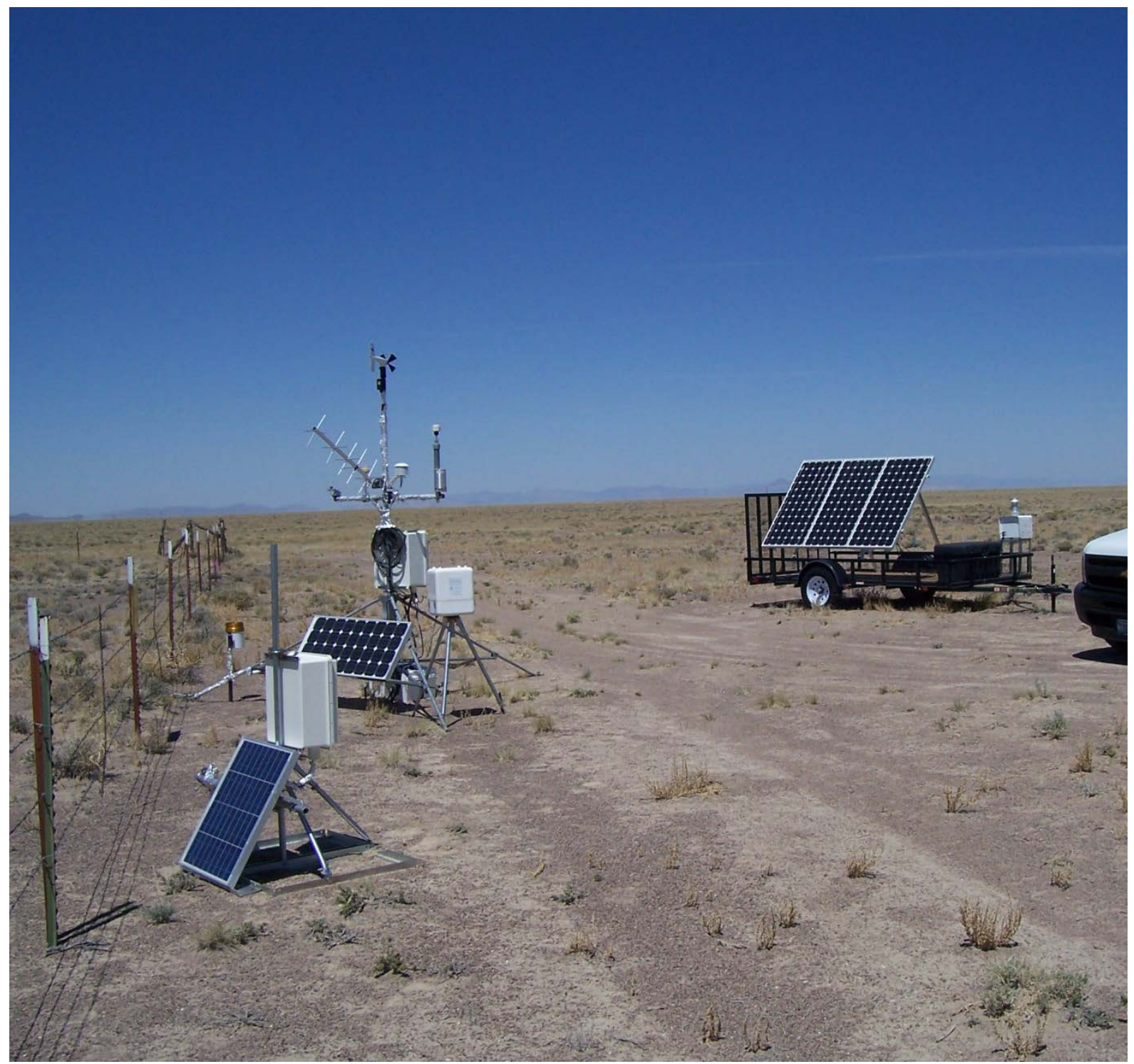

Figure 5. The solar powered air sampler, saltation sensor, and meteorological tower (center right, foreground left, center left, respectively) at Station 402 are located along the north fence that bounds the Clean Slate 1 contamination area.

\section{RADIOLOGICAL ASSESSMENT OF AIRBORNE PARTICULATES}

Airborne dust particles are collected continuously using $\mathrm{Hi}-\mathrm{Q}^{\mathrm{TM}}$ dust collectors located at each of the TTR air monitoring stations. A glass fiber filter (diameter: $10 \mathrm{~cm}$ [4 in], pore size; $0.3 \mu \mathrm{m}$ ) is installed at Station 400 . Cellulose fiber filters (diameter: $10 \mathrm{~cm}$ [4 in], pore size: 20 to $25 \mu \mathrm{m}$ ) are used at Stations 401 and 402. The Hi-Q equipment draws ambient air through the filters at a rate of approximately $56.6 \mathrm{lpm}(2 \mathrm{cfm})$ and is designed to maintain the same flow rate as dust gathers on the filter. The total volume of air passed through the filter and the total hours of operation are recorded as filters are recovered from the equipment and new filters are deployed every two weeks. Filters are weighed before and after deployment to determine the mass of particulates collected. They are accumulated and 
periodically submitted to the Radiological Services Laboratory at the University of Nevada, in Las Vegas, Nevada for gross alpha, gross beta, and gamma spectroscopy assessment. The gross alpha and gross beta observations for CY2012 are summarized in Tables 3 and 4, respectively, below.

Filters collected during CY2012 were deployed between December 28, 2011 and December 28, 2012. This generated 26 air particulate filter samples for Stations 400 and 401. Only 25 particulate samples were collected from Station 402 because the air pump failed during the last 2-week period of 2012 (December 12 to December 26).

The mean annual gross alpha activity (Table 3) ranged from $2.01 \times 10^{-15}$ microCuries per milliliter $(\mu \mathrm{Ci} / \mathrm{mL})$ at Station 401 to $3.69 \times 10^{-15} \mu \mathrm{Ci} / \mathrm{mL}$ at Station 400 . The mean annual gross beta activity (Table 4) ranged from $0.81 \times 10^{-14} \mu \mathrm{Ci} / \mathrm{mL}$ at Station 401 to $2.09 \mathrm{x}$ $10^{-14} \mu \mathrm{Ci} / \mathrm{mL}$ at Station 400 . The higher gross alpha and gross beta concentrations observed at Station 400 are likely due to the use of the small pore size glass-fiber filters at that station. The small pore size will result in the filter collecting smaller particles than the cellulose fiber filters which have a larger pore size.

Table 3. Gross Alpha Results for TTR Sampling Stations 2012

\begin{tabular}{cccccc}
\hline Sampling & Number & \multicolumn{4}{c}{ Concentration $\left(\times 10^{-15} \mu \mathrm{Ci} / \mathrm{mL}\left[3.7 \times 10^{-5}\right.\right.$ Becquerel $\left.\left.(\mathrm{Bq}) / \mathrm{m}^{3}\right]\right)$} \\
\cline { 3 - 5 } & of & Mean & $\begin{array}{c}\text { Standard } \\
\text { Deviation }\end{array}$ & Minimum & Maximum \\
\hline Station 400 & 26 & 3.69 & 1.87 & 0.92 & 9.15 \\
Station 401 & 26 & 2.01 & 1.04 & 0.32 & 4.36 \\
Station 402 & 25 & 2.80 & 1.53 & 0.73 & 5.76 \\
\hline
\end{tabular}

NOTES: $\mathrm{Bq}=$ Becquerel; $\mathrm{m}^{3}$ = cubic meter; $\mu \mathrm{Ci} / \mathrm{ml}=$ microcurie per milliliter; $\mathrm{TTR}=$ Tonopah Test Range; glass-fiber filters at Station 400 retain particulates greater than $0.3 \mu \mathrm{m}$; cellulose-fiber filters at Stations 401 and 402 retain particulates greater than $20 \mu \mathrm{m}$.

Table 4. Gross Beta Results for TTR Sampling Stations 2012

\begin{tabular}{cccccc}
\hline \multirow{2}{*}{$\begin{array}{c}\text { Sampling } \\
\text { Location }\end{array}$} & $\begin{array}{c}\text { Number } \\
\text { of } \\
\text { samples }\end{array}$ & \multicolumn{4}{c}{ Concentration $\left(\mathrm{x} 10^{-14} \mu \mathrm{Ci} / \mathrm{mL}\left[3.7 \times 10^{-4}\right.\right.$ Becquerel $\left.\left.(\mathrm{Bq}) / \mathrm{m}^{3}\right]\right)$} \\
\cline { 3 - 6 } & 26 & Mean & $\begin{array}{c}\text { Standard } \\
\text { Deviation }\end{array}$ & Minimum & Maximum \\
\hline Station 400 & 2.09 & 0.42 & 1.56 & 3.27 \\
Station 401 & 26 & 0.81 & 0.22 & 0.46 & 1.37 \\
Station 402 & 25 & 1.04 & 0.35 & 0.19 & 1.87 \\
\hline
\end{tabular}

NOTES: $\mathrm{Bq}=$ Becquerel; $\mathrm{m}^{3}$ = cubic meter; $\mu \mathrm{Ci} / \mathrm{ml}=$ microcurie per milliliter; $\mathrm{TTR}=$ Tonopah Test Range; glass-fiber filters at Station 400 retain particulates greater than $0.3 \mu \mathrm{m}$; cellulose-fiber filters at Stations 401 and 402 retain particulates greater than $20 \mu \mathrm{m}$. 
Table 5 gives the gross alpha and gross beta concentrations reported for CEMP stations surrounding the TTR. The TTR monitoring stations exhibit higher gross alpha values than any of the surround CEMP stations and gross beta values that are lower than most of the surrounding CEMP stations.

Table 5. Mean annual gross alpha and gross beta concentrations for 2011 reported at CEMP stations that surround the TTR (from NSTec, 2012).

\begin{tabular}{lcccccc}
\hline \multirow{2}{*}{$\begin{array}{c}\text { Sampling } \\
\text { Location }\end{array}$} & Mean & Minimum & Maximum & Mean & Minimum & Maximum \\
\cline { 2 - 7 } Goldfield & 1.05 & 0.48 & 1.88 & 2.09 & 1.12 & 6.03 \\
Medlin's & na & na & na & na & na & na \\
Nyala Ranch & 1.03 & 0.49 & 1.88 & 2.21 & 1.37 & 4.43 \\
Rachel & 1.03 & 0.56 & 1.66 & 2.24 & 1.21 & 7.69 \\
Sarcobatus & 1.83 & 0.51 & 4.61 & 2.32 & 1.29 & 6.38 \\
Stone Cabin & 0.91 & 0.47 & 1.99 & 1.8 & 0.69 & 6.37 \\
Tonopah & 1.08 & 0.41 & 2.14 & 2.12 & 1.19 & 6.72 \\
Twin Springs & 0.95 & 0.53 & 1.81 & 2.06 & 1.15 & 5.23 \\
Warm & na & na & na & na & na & na \\
\hline
\end{tabular}

na = value not available

Gamma spectroscopy identified only naturally occurring radionuclides in the particulate samples collected from TTR air monitoring Stations 400, 401, and 402 during CY2012 (Table 6). No anthropogenic gamma emitting radionuclides were detected. No plutonium-239 or -240 or any indicators of these radionuclides were detected.

Table 6. Only naturally occurring radionuclides were identified by gamma spectroscopy analysis of the CY2012 particulate samples.

\begin{tabular}{lccc}
\hline \multicolumn{1}{c}{ Ion } & Station 400 & Station 401 & Station 402 \\
\hline Beryllium-7 (Be-7) & common & common & common \\
Lead-210 (Pb-210) & common & common & common \\
Potassium-40 (K-40) & none & three samples & none \\
Protactinium-234m (Pa-234m) & none & one sample & one sample \\
\hline
\end{tabular}

\section{GAMMA RADIATION EXPOSURE ASSESSMENT}

Gamma radiation exposure is measured using a Pressurized Ion Chamber (PIC) detector. The PIC detector is used because of its sensitivity which may permit detection of low-level exposures that go undetected by other monitoring methods. PIC detectors are deployed to detect changes in ambient gamma radiation due to human activities. In the absence of such activities, ambient gamma radiation rates vary naturally among locations, reflecting differences in altitude (cosmic radiation) and radioactivity in the soil (terrestrial 
radiation). Additionally, slight variations in gamma radiation at a single location may be due to changes in weather (UNSCEAR, 2000).

Gamma detections by the PIC sensors are influenced by precipitation and changes in barometric pressure. During 2011, elevated gamma readings, 10 to 50 percent above the normal average background values, observed by the CEMP network that surrounds the Nevada National Security Site (NNSS) were attributed to "rainout” of globally distributed radionuclides during precipitation events and to low barometric pressure events which can result in the release of increased amounts of naturally occurring radon and its daughter products from soil and rock substrates (NSTec, 2012).

PIC data collected at the TTR air monitoring stations measure gamma radiation exposure every 3 seconds; these measurements are averaged every 10 minutes before being recorded in the station data base. Daily averages of gamma exposure rates are presented in Figure 6 and are summarized for CY2012 in Table 7. Daily averages are reported in microroentgens per hour ( $\mu \mathrm{R} / \mathrm{hr})$ and total annual exposure is reported in milliroentgens per year (mR/yr). The highest daily average exposure $(21.25 \mu \mathrm{R} / \mathrm{hr})$ and the highest total annual exposure (186.15 mR/yr) occur at Station 401 adjacent to Clean Slate 3. The annual values reported for Station 400 are of approximately the same magnitude, but slightly lower than, the values reported for Station 402.

Table 8 presents the PIC data reported by the NNSS CEMP stations surrounding the TTR (NSTec, 2012). TTR stations 400 and 402 report gamma radiation exposure values in the upper range of the 2011 values for the CEMP stations. The gamma radiation exposure rate reported for Station 402 is slightly higher than the 2011 values reported for the CEMP stations.

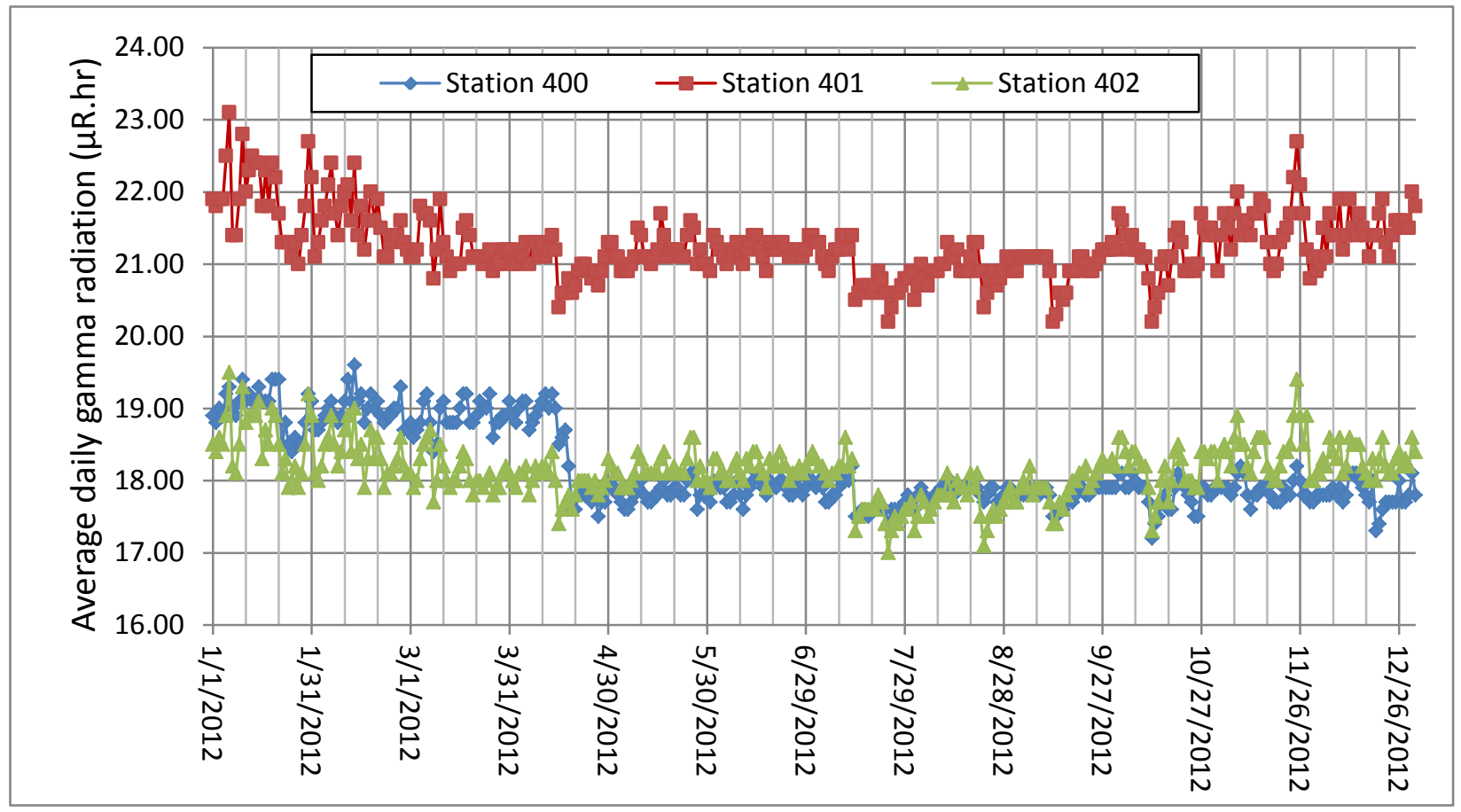

Figure 6. Daily average gamma radiation exposure at TTR air monitoring stations 400, 401, and 402 for CY2012. 
Table 7. Average daily and total annual gamma radiation exposure at TTR air monitoring stations 400, 401, and 402 during CY2012.

\begin{tabular}{|c|c|c|c|c|c|}
\hline $\begin{array}{l}\text { Sampling } \\
\text { Location }\end{array}$ & $\begin{array}{l}\text { Average } \\
\text { Gamma } \\
\text { Exposure } \\
(\mu \mathrm{R} / \mathrm{hr}) \\
\end{array}$ & $\begin{array}{c}\text { Stand. Dev. } \\
(\mu \mathrm{R} / \mathrm{hr})\end{array}$ & $\begin{array}{l}\text { Maximum } \\
(\mu \mathrm{R} / \mathrm{hr})\end{array}$ & $\begin{array}{l}\text { Minimum } \\
(\mu \mathrm{R} / \mathrm{hr})\end{array}$ & $\begin{array}{l}\text { Annual Total } \\
\text { Gamma } \\
\text { Exposure } \\
\text { (mR/yr) }\end{array}$ \\
\hline Station & 18.15 & 0.55 & 19.60 & 17.20 & 158.99 \\
\hline Station & 21.25 & 0.44 & 23.10 & 20.20 & 186.15 \\
\hline Station & 18.62 & 0.92 & 21.20 & 17.00 & 163.11 \\
\hline
\end{tabular}

Table 8. Average daily and annual gamma radiation exposure values for 2011 reported at CEMP stations that surround the TTR (from NSTec, 2012).

\begin{tabular}{lccccc}
\hline \multirow{2}{*}{$\begin{array}{c}\text { Sampling } \\
\text { Location }\end{array}$} & Mean & $\begin{array}{c}\text { Standard } \\
\text { Deviation }\end{array}$ & Minimum & Maximum & $\begin{array}{c}\text { Annual } \\
\text { Exposure } \\
\text { (mR/yr) }\end{array}$ \\
\cline { 2 - 5 } Goldfield & 14.90 & 0.41 & 13.9 & 15.9 & 130.52 \\
Medlin's Ranch & 16.80 & 0.33 & 15.80 & 17.8 & 147.17 \\
Nyala Ranch & 14.35 & 0.86 & 12.6 & 16.1 & 125.71 \\
Rachel & 14.95 & 0.90 & 13.2 & 16.7 & 130.96 \\
Sarcobatus Flats & 16.40 & 0.31 & 15.4 & 17.4 & 143.66 \\
Stone Cabin Ranch & 16.95 & 0.58 & 15.7 & 18.2 & 148.48 \\
Tonopah & 16.20 & 0.30 & 15.3 & 17.1 & 141.91 \\
Twin Springs & 19.90 & 0.64 & 18.1 & 21.7 & 174.32 \\
Warm Springs & 19.60 & 0.55 & 17.9 & 21.3 & 171.70 \\
\hline
\end{tabular}

\section{WEATHER CONDITIONS AND OTHER ENVIRONMENTAL PARAMETERS}

Air temperature trends recorded during the year at Stations 400, 401, and 402 between January, 12012 and December 31, 2012 are shown in Figures 7 and 8. Three traces shown on Figure 7 depict maximum, average, and minimum daily temperature based on hourly average temperature for Stations 400, 401, and 402. Maximum temperature during summer was between 32 to $38^{\circ} \mathrm{C}\left(90-100^{\circ} \mathrm{F}\right)$ and minimum temperature during winter was between -23 to $-12^{\circ} \mathrm{C}\left(-10\right.$ to $\left.10^{\circ} \mathrm{F}\right)$. On most days, maximum temperature is about $8^{\circ} \mathrm{C}\left(15^{\circ} \mathrm{F}\right)$ above daily average air temperature and the minimum daily air temperature is about $8^{\circ} \mathrm{C}$ $\left(15^{\circ} \mathrm{F}\right)$ below the average, resulting in a diurnal temperature swing of about $16^{\circ} \mathrm{C}\left(30^{\circ} \mathrm{F}\right)$.

Air temperature trends between all three stations are very similar, as can be clearly seen in Figure 8, and as expected considering the close proximity and relatively small change in elevation between the three stations. The average air temperature at Station 400 is higher when compared to Stations 401 and 402, most likely because Station 400 is located near several buildings and the presence of nearby paved roads that absorb more heat during the day. This area appears to have the effect of a small urban heat island that averages out temperature extremes because of the increase in heat capacity and less natural air circulation. 

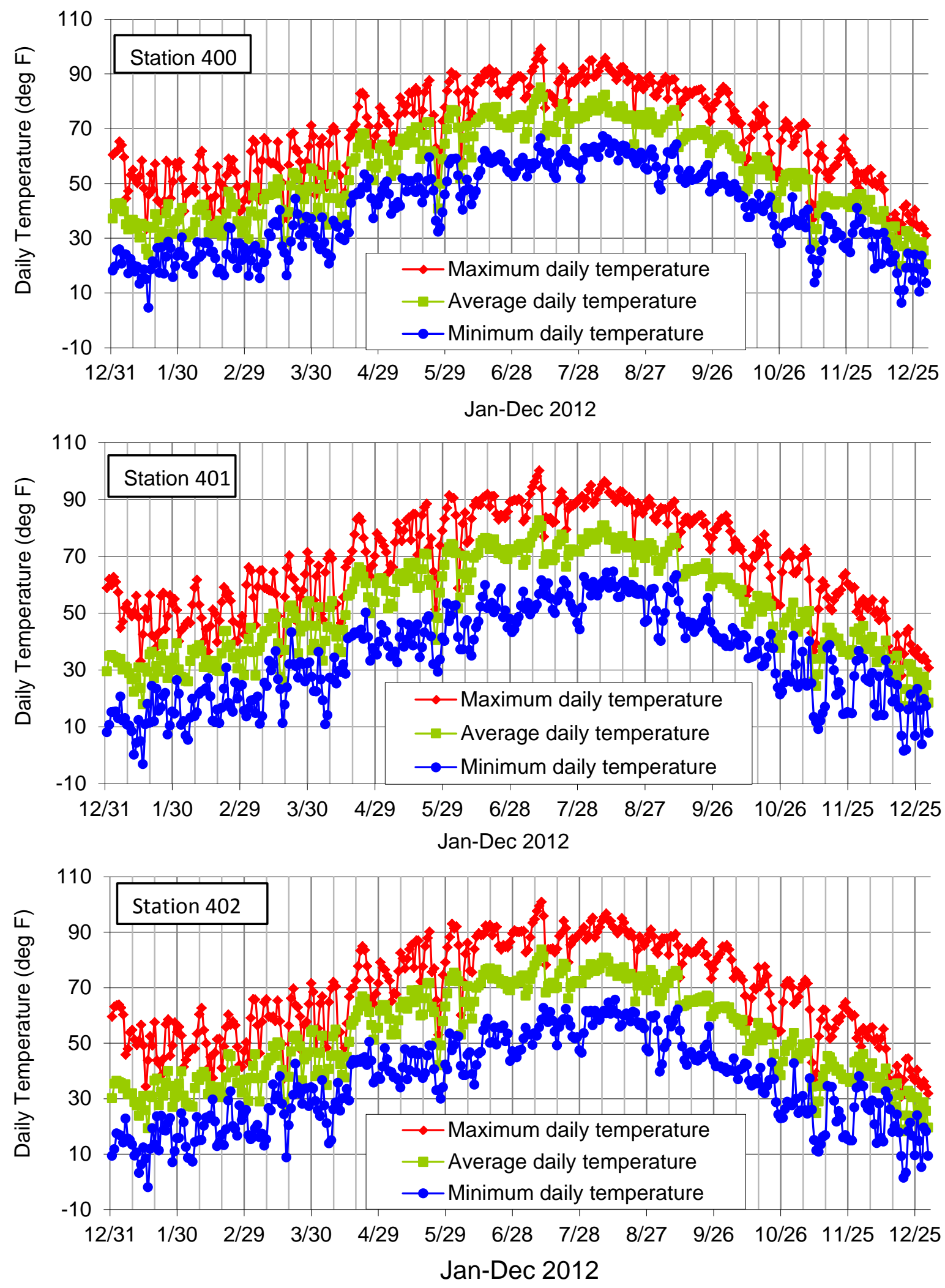

Figure 7. Ambient air temperature for Stations 400, 401, and 402 for CY2012. 


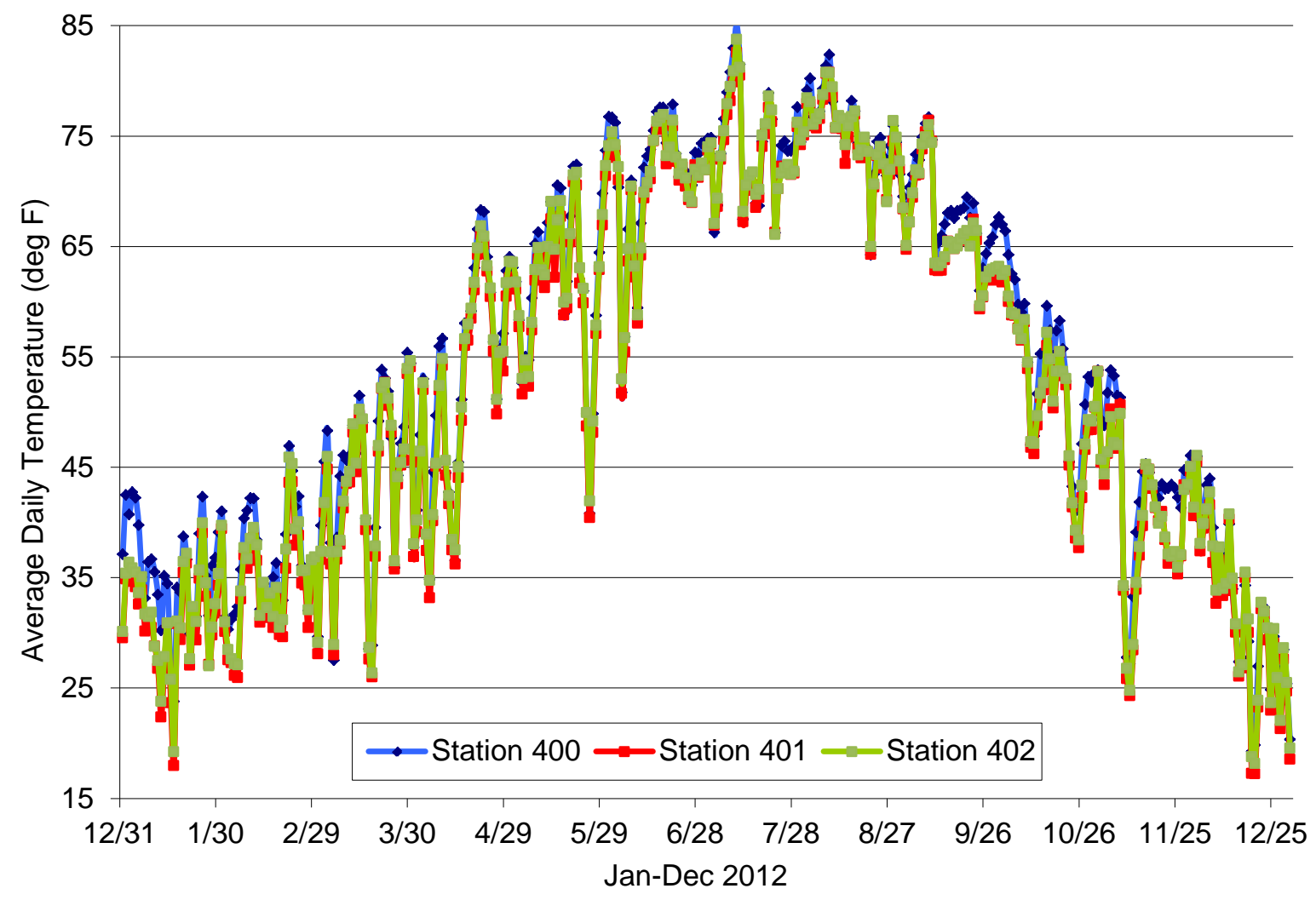

Figure 8. Average ambient air temperature for Stations 400, 401, and 402 CY2012.

The daily average soil temperature for all three TTR stations is shown in Figure 9. Soil temperature is acquired using temperature probes that are made of thermocouple wire buried at the depth of 10 to $13 \mathrm{~cm}$ (4 to 5 inches) in an effort to reflect the potential for drying of the surficial soil. Generally there are minor differences in soil temperature readings between the stations. These minor differences may be explained in part by differences in local soil thermal conductivity, soil moisture, vegetation cover, probe burial depth, and exposure of the temperature probe. From late September to early November, soil temperature at Station 400 appears to be notably warmer than at Stations 401 and 402. Late summer rain events may be the cause of these differences. The gravel ground cover at Station 400 loses moisture more rapidly than do the fine grain soils at Stations 401 and 402 . The absence of soil moisture at Station 400 would permit a stronger response of soil temperature to air temperature compared to the response observed at Station 401 and 402 where soil moisture is more readily retained. Data from Station 401 (Figure 10) illustrates the close relationship between soil temperature and air temperature. Both the regression coefficient and the $\mathrm{x}$ coefficient, or slope of the regression line, express the strong dependency of the soil temperature on the air temperature. The intercept of the regression equation indicates that the soil temperature tends to be warmer by almost $7^{\circ} \mathrm{F}$ than the air temperature. 


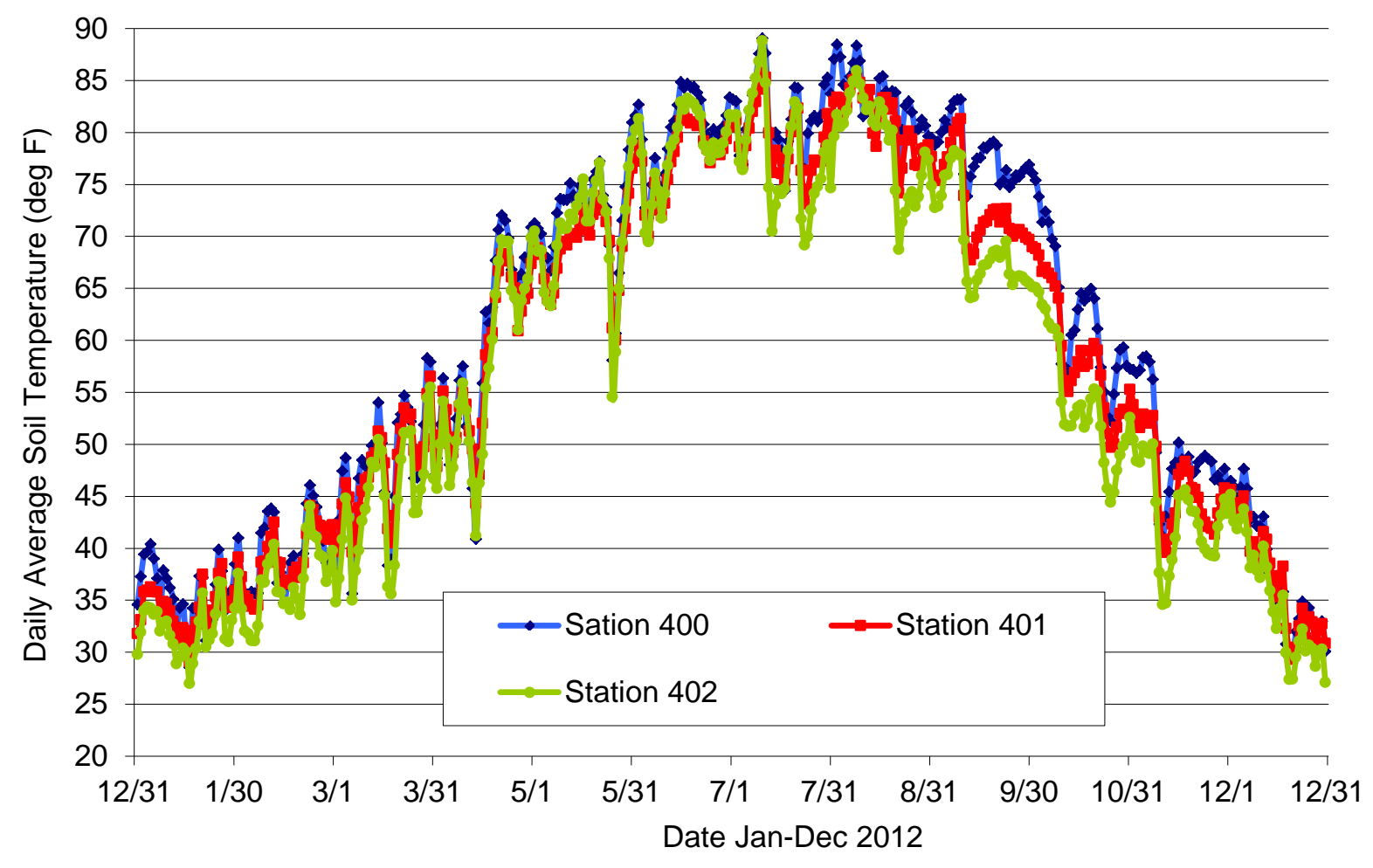

Figure 9. Average ambient soil temperature for Stations 400, 401, and 402 for CY2012.

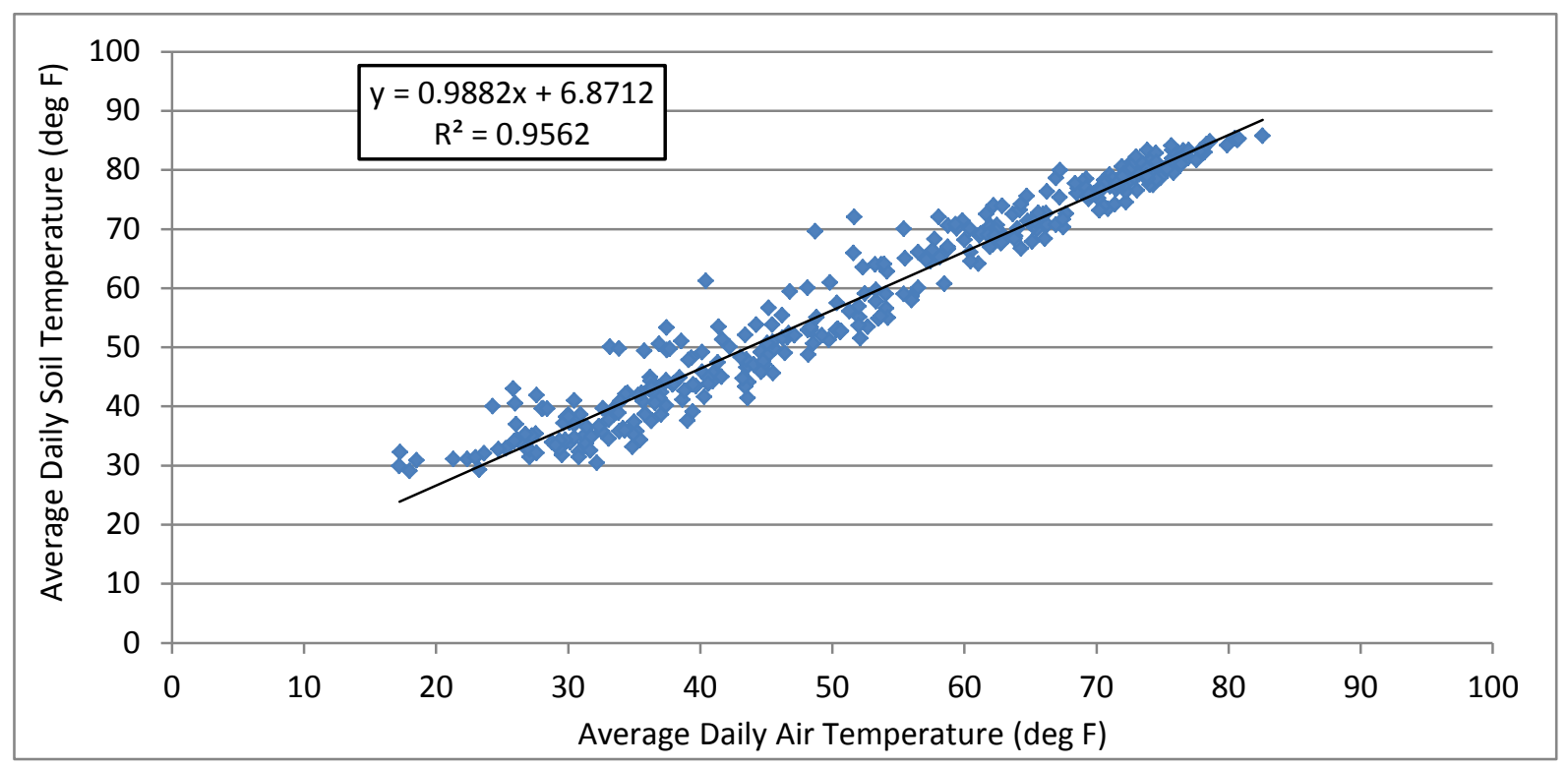

Figure 10. Comparison of average air and average soil temperatures by regression illustrates the close relationship between the two parameters at Station 401. 
Total cumulative precipitation for Stations 400, 401, and 402 in the period between January 1, 2012 and December 31, 2012 are shown in Figure 11. All three stations reported zero precipitation in January; the line representing Station 402 is drawn on top of the lines representing the other two stations. Total precipitation for the calendar year varied between $102 \mathrm{~mm}$ (4 inches) for Station 400 to above $190.5 \mathrm{~mm}$ (7.5 inches) for Station 402. Annual precipitation at Station 401 was about $152.4 \mathrm{~mm}$ (6 inches). Most rainfall events were wide spread enough to be recorded by all three stations, and typically were of similar magnitudes. However, the rainfall event that occurred in mid-July, 2012, resulted in significant differences between stations; Station 402 at CS 1 recorded more than $63.5 \mathrm{~mm}$ (2.5 inches) of rain, whereas Station 400 recorded approximately $12.7 \mathrm{~mm}$ (0.5 inches) and Station 401 recorded approximately $20.3 \mathrm{~mm}$ (0.8 inches) for the same period.

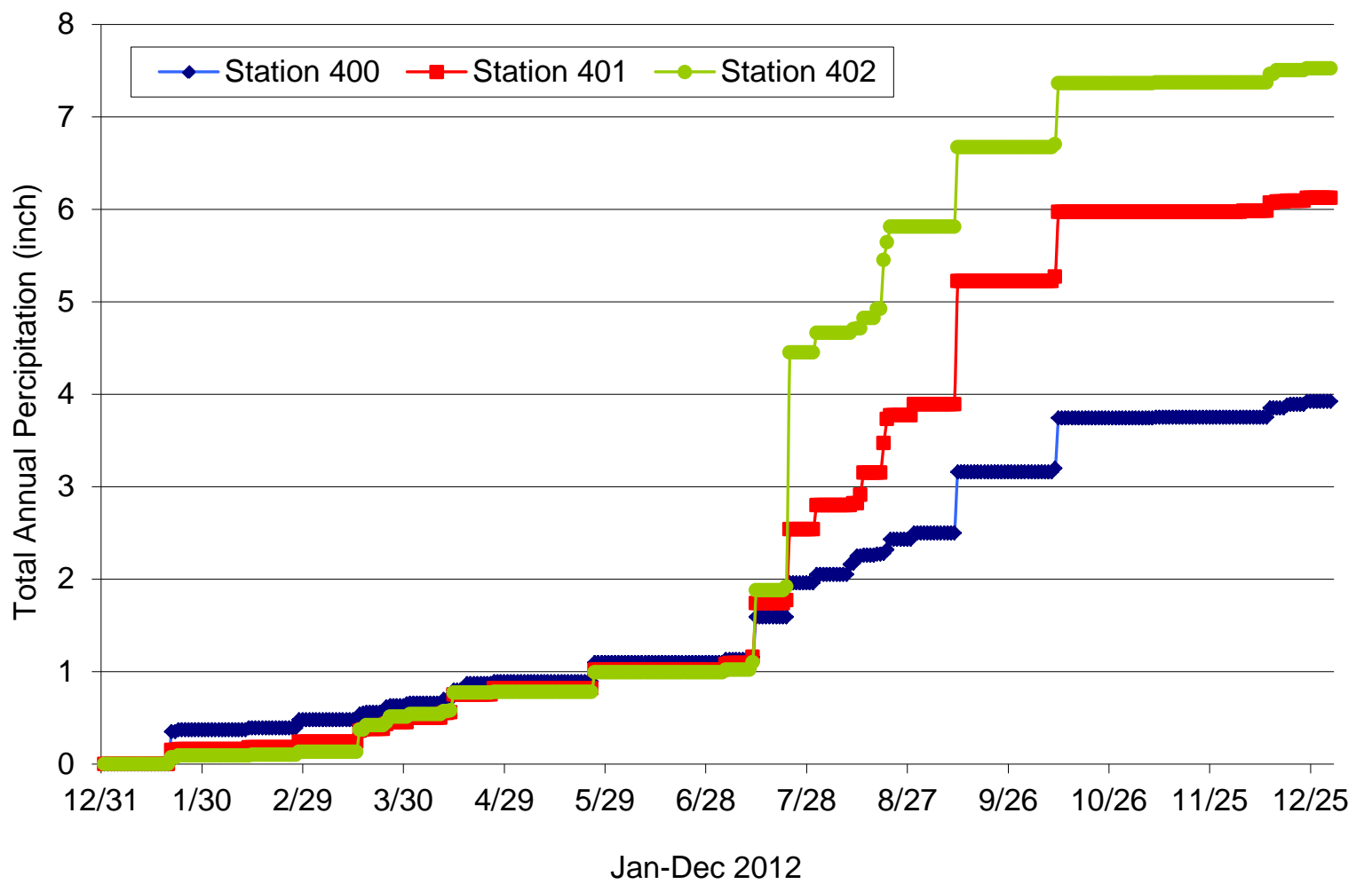

Figure 11. Cumulative precipitation for Stations 400, 401, and 402 for CY2012.

Average precipitation for the three stations during CY2012 was slightly less than $152.4 \mathrm{~mm}$ (6 inches), which is above the historic average annual precipitation of $129.03 \mathrm{~mm}$ (5.08 inches) measured at the Tonopah Airport during the years 1954 through 2013 (www.wrcc.dri.edu/cgi-bin/cliMAIN.pl?nv8170, accessed May 17, 2013). Also, non-heated rain gages are used at the three stations, so snowfall may have been underestimated if the gages froze or snow was blown out of the gage prior to melting.

Soil volumetric water content was monitored at all three stations in the top $5 \mathrm{~cm}$ (2 inches) of soil using Time Domain Reflectometry (TDR) probes. The TDR probes provide an 
estimate of soil water content based on direct measurement of soil conductivity. The TDR indicates relative changes in soil water content associated with rain events and drying periods. The water content of this top layer of soil is most relevant to soil migration when soil is exposed to high winds. Sufficiently high soil moisture content is expected to diminish the soil material available for re-distribution by wind because moisture helps to bind the soil particles together. Figure 12 shows the volumetric water content (VWC) of the top soil layer at Stations 400, 401, and 402. Increases in soil VWC coincide with precipitation events and subsequent decreases in VWC correspond to drying. However, the soil VWC, by itself, is not a reliable indicator of soil. For example, short intense rain events, which would be expected to increase soil stability due to the addition of moisture, may break up the soil crust and release fine soil particles for transport when exposed to wind.

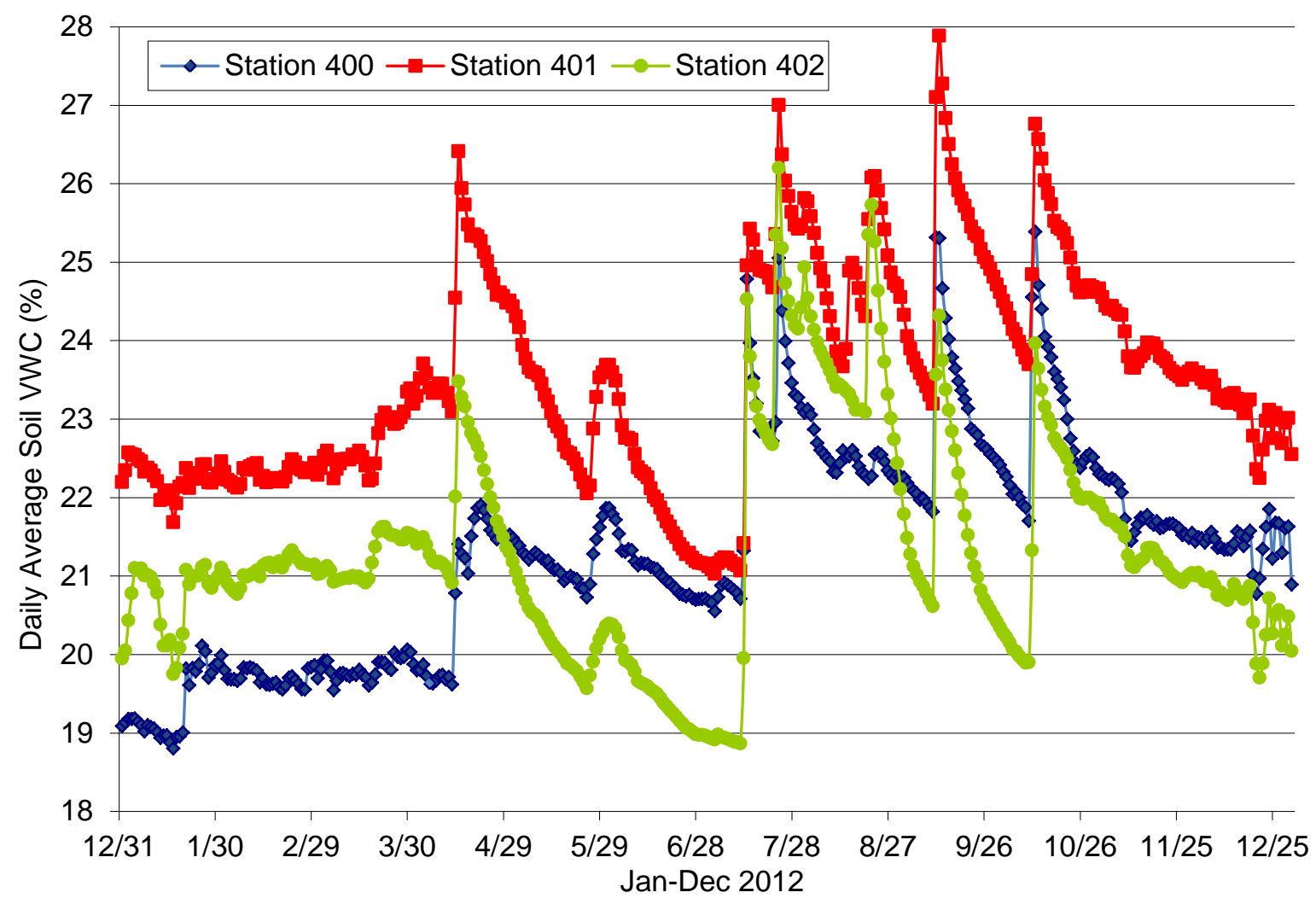

Figure 12. Soil volumetric water content for Stations 400, 401, and 402 for CY2012.

Wind is a major mechanism that drives soil migration at TTR; thus, it is important to monitor wind in conjunction with real-time particulate matter (PM) concentrations, allowing determination of conditions under which dust transport by wind occurs. Annual (Figure 13) and quarterly (not shown) wind rose diagrams have been developed for all three stations for calendar year 2012. Each station has two wind roses covering the same time period in Figure 14: the one on the left shows all wind speeds and their contribution to the overall wind rose and the one on the right shows only winds above $24 \mathrm{~km} / \mathrm{hr}$ (15 miles per hour [mph]). In general, winds above $24 \mathrm{~km} / \mathrm{hr}\left(15 \mathrm{mph}\right.$ ) result in elevated $\mathrm{PM}_{10}$ (particulate matter of aerodynamic radius of less than 10 micro-meters) concentrations in the air. $\mathrm{PM}_{10}$ is an indicator of small size particles that are suspended in air and can be easily inhaled. As seen in 
the multiple wind roses in Figure 13, the most prevalent winds are from the south and northwest during the year, especially the winds above $24 \mathrm{~km} / \mathrm{hr}$ (15 mph). The strong southern component is present throughout the year and is especially dominant during the summer months, whereas the northwestern component is present during the winter months, diminishing during the warmer months.

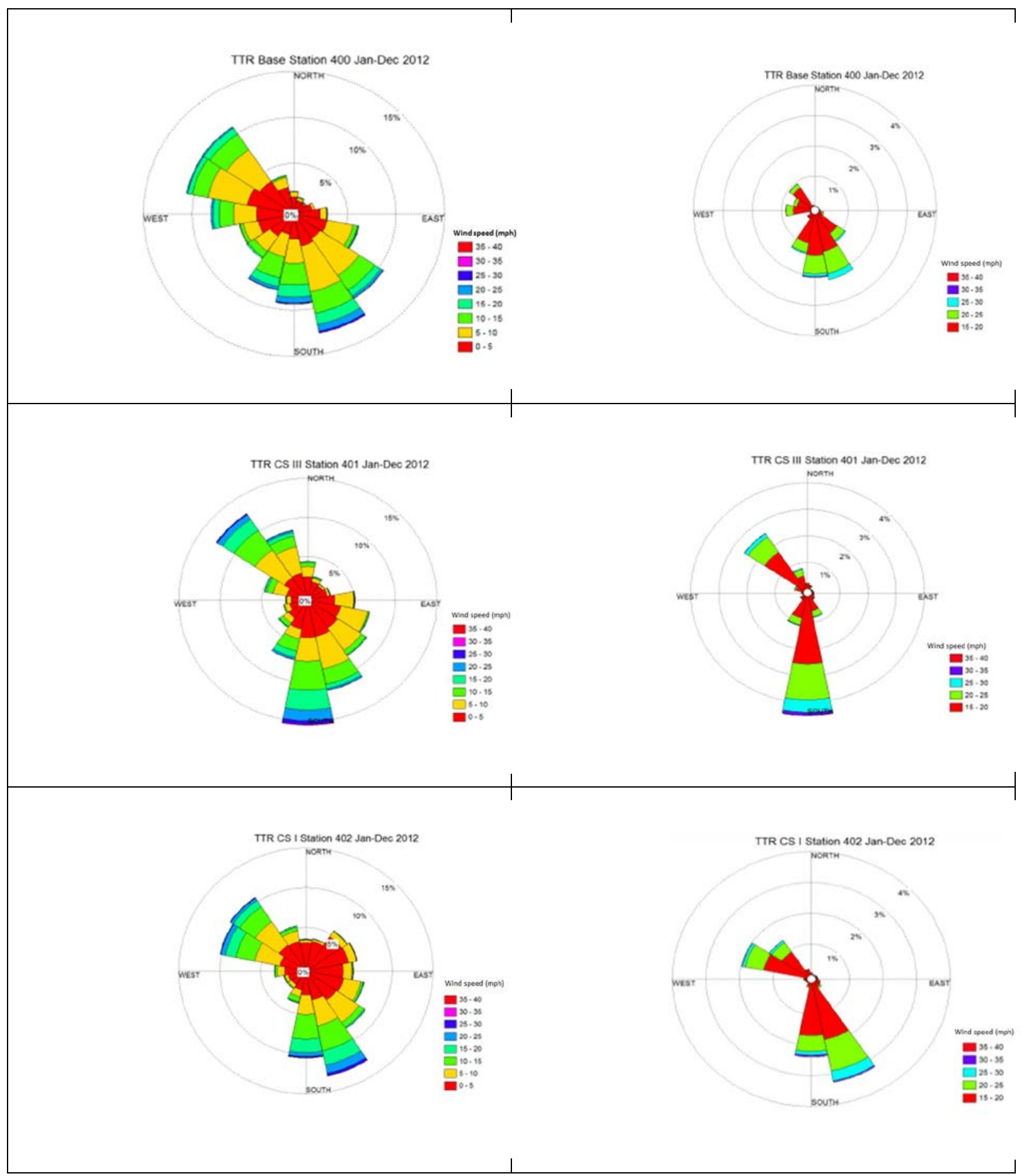

Figure 13. Annual wind roses for Stations 400, 401, and 402 for CY2012; left side graphics depict all winds, right side graphics depict winds greater than $24 \mathrm{~km} / \mathrm{hr}$ (15 mph). 


\section{OBSERVATIONS OF SOIL TRANSPORT BY SALTATION}

Saltation is the mechanism by which larger soil particles are transported across the ground surface. Saltation and suspension, dust, are the most likely mechanisms for transporting radionuclides from the contamination sites. Generally, saltation involves particles greater than about $50 \mu \mathrm{m}$. Particles are dislodged and carried small distances in the air before falling to the ground. Transport paths usually follow a parabolic trajectory; the particles essentially bounce across the ground. The amount of time the particles are in the air and the distances traveled are functions of wind speed and particle mass. Saltation is important because the impact of saltated particles dislodges smaller particles and ejects them into the air where they are transported by suspension.

The Sensit H11-LIN ${ }^{\mathrm{TM}}$ is deployed at TTR air monitoring Stations 401 and 402 to measure soil particles that bounce across the ground surface. The sensor impact area, which was set $10 \mathrm{~cm}$ (4 inches) above the ground surface, wraps completely around the vertically oriented instrument and is capable of registering impacts from any direction. The impact area is made of piezoelectric material that converts particle impacts to electrical impulses which are recorded. Particle counts are summed over 10-minute intervals and stored on the station data logger. Presently the saltation sensors are located in proximity to the metrological towers at each station in areas free of recent disturbances and vegetation that might interfere with their operation.

Because rain drop impact dislodges soil particles and ejects particles into the air, counts on the saltation sensors increase during precipitation events. Although precipitation events are typically accompanied by significant winds, counting periods that are coincident with precipitation are removed from the data set so that analyses can be focused on the wind driven saltation. Prior to analysis of the data, saltation data associated with 23 precipitation events were removed from the record at Station 401 (Table 9). At Station 402, saltation data associated with 29 precipitation events were removed from the data record prior to analysis (Table 10).

Saltated particle counts are strongly dependent on wind speed. The relationship between wind speed and saltation particle counts was investigated by determining the average number of particle counts/10-minute interval for wind speeds categorized in 5-mph wind speed classes (Table 9) after removing those intervals influenced by rain fall. Figure 14 shows that the relationship between wind speed and saltation particle count is approximately exponential. As wind speed increases linearly, the particle count increases exponentially. Below the $35 \mathrm{mph}$ wind class, both Stations 401 and 402 show similar saltation counts; above $35 \mathrm{mph}$ the saltation counts at Station 401 are notably greater than observed at Station 402. The presence of saltation material is more limited at Station 402 than at Station 401. With that single difference there appears to be no significant differences between the saltable material available at the two sites. 
Table 9. Average saltation particle counts by wind speed class at TTR air monitoring Stations 401 and 402.

\begin{tabular}{cccc}
\hline Wind Speed Class (mph) & Duration (hours) & $\begin{array}{c}\text { Average Wind Speed } \\
(\mathrm{mph})\end{array}$ & $\begin{array}{c}\text { Average Particle Counts } \\
\text { (count/10-min) }\end{array}$ \\
\hline Station 401 & 3783.3 & 2.9 & 0.03 \\
$0-5$ & 2729.7 & 7.1 & 0.20 \\
$5-10$ & 1298.7 & 12.3 & 0.98 \\
$10-15$ & 625.5 & 17.1 & 2.14 \\
$15-20$ & 268.7 & 22.0 & 6.02 \\
$20-25$ & 64.8 & 26.6 & 19.59 \\
$25-30$ & 12.8 & 31.6 & 31.97 \\
$30-35$ & 0.7 & 36.4 & 90.25 \\
$>35$ & 8784.2 & & 0.01 \\
Total & & & 0.19 \\
\hline Tation 402 & 4439.5 & 2.8 & 0.92 \\
$5-10$ & 2235.2 & 7.0 & 2.67 \\
$10-15$ & 1218.5 & 12.3 & 7.73 \\
$15-20$ & 584.8 & 17.2 & 21.35 \\
$20-25$ & 239.8 & 22.1 & 30.55 \\
$25-30$ & 55.7 & 26.8 & 60.33 \\
$30-35$ & 10.0 & 31.4 & \\
$>35$ & 0.5 & 35.6 & \\
\hline 0 - 25 & 8784.0 & & \\
\hline
\end{tabular}




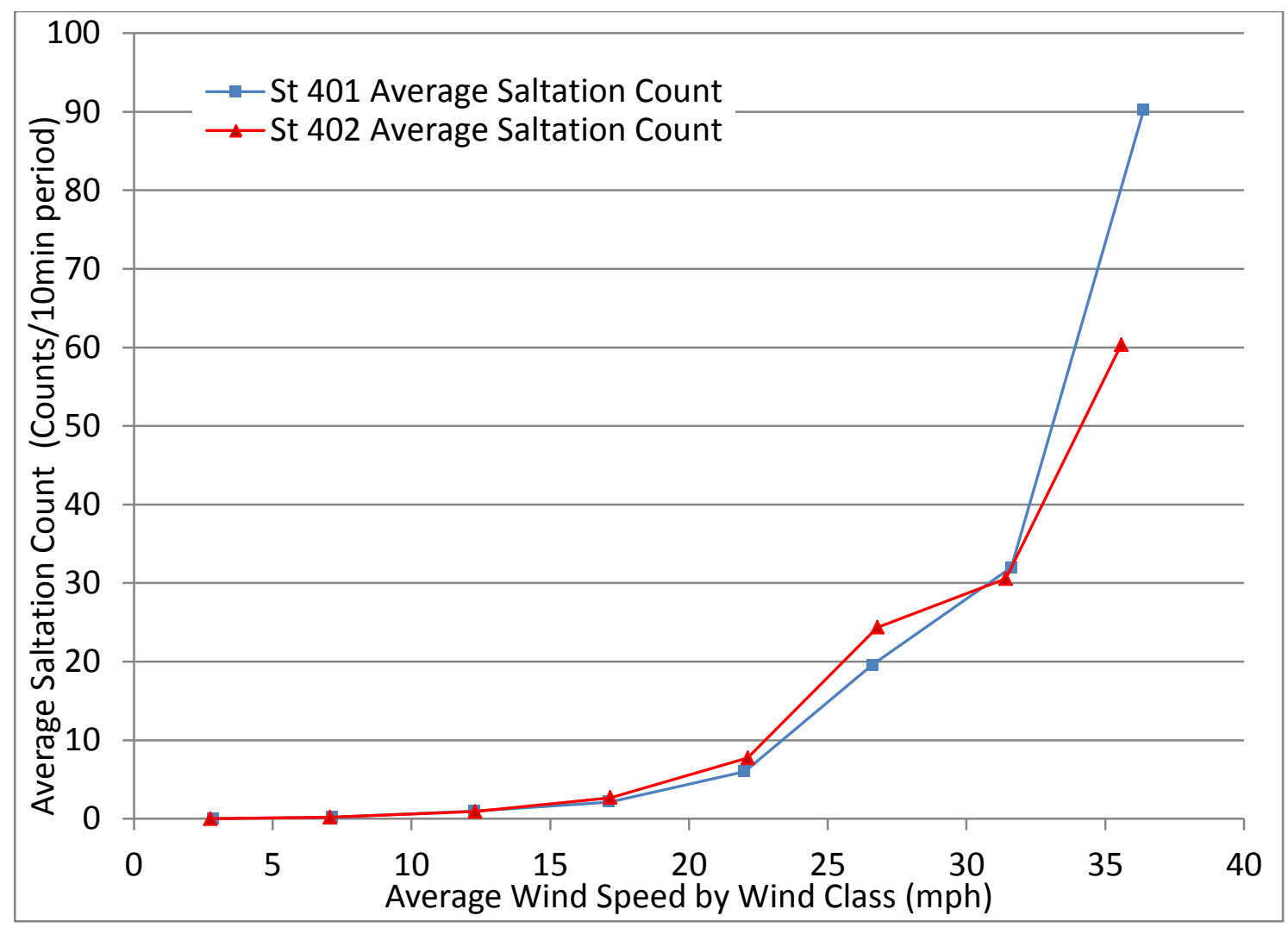

Figure 14. Average saltation counts increase exponentially as the wind speed increases at both TTR air monitoring Stations 401 and 402.

Because saltated particles are likely to dislodge and eject smaller particles from the soil surface, the relationship between saltation particle counts and $\mathrm{PM}_{10}$ concentrations is important. A correlation analysis was implemented to investigate this relationship. Strong correlation between high saltation values and high $\mathrm{PM}_{10}$ values would indicate that strong winds are driving the saltation activity which in turn contributes to the fine dust emissions. Figure 15 shows the correlation between saltation counts and $\mathrm{PM}_{10}$ concentration at Stations 401 and 402. The correlation coefficients at both stations are greater than 90 percent $\left(\mathrm{R}^{2}=\right.$ 0.9308 at Station 401 and 0.9839 at Station 402). The larger slope for the Station 402 data suggests that the $\mathrm{PM}_{10}$ concentration at Station 402 is more strongly influenced by saltation effects than at Station 401.The correlation analyses indicate that the fine dust is locally emitted rather than transported from distant sources. Further, the analyses indicate that soil migration occurs when sustained winds exceed 37 - $40 \mathrm{~km} / \mathrm{hr}$ (20-25 mph). 


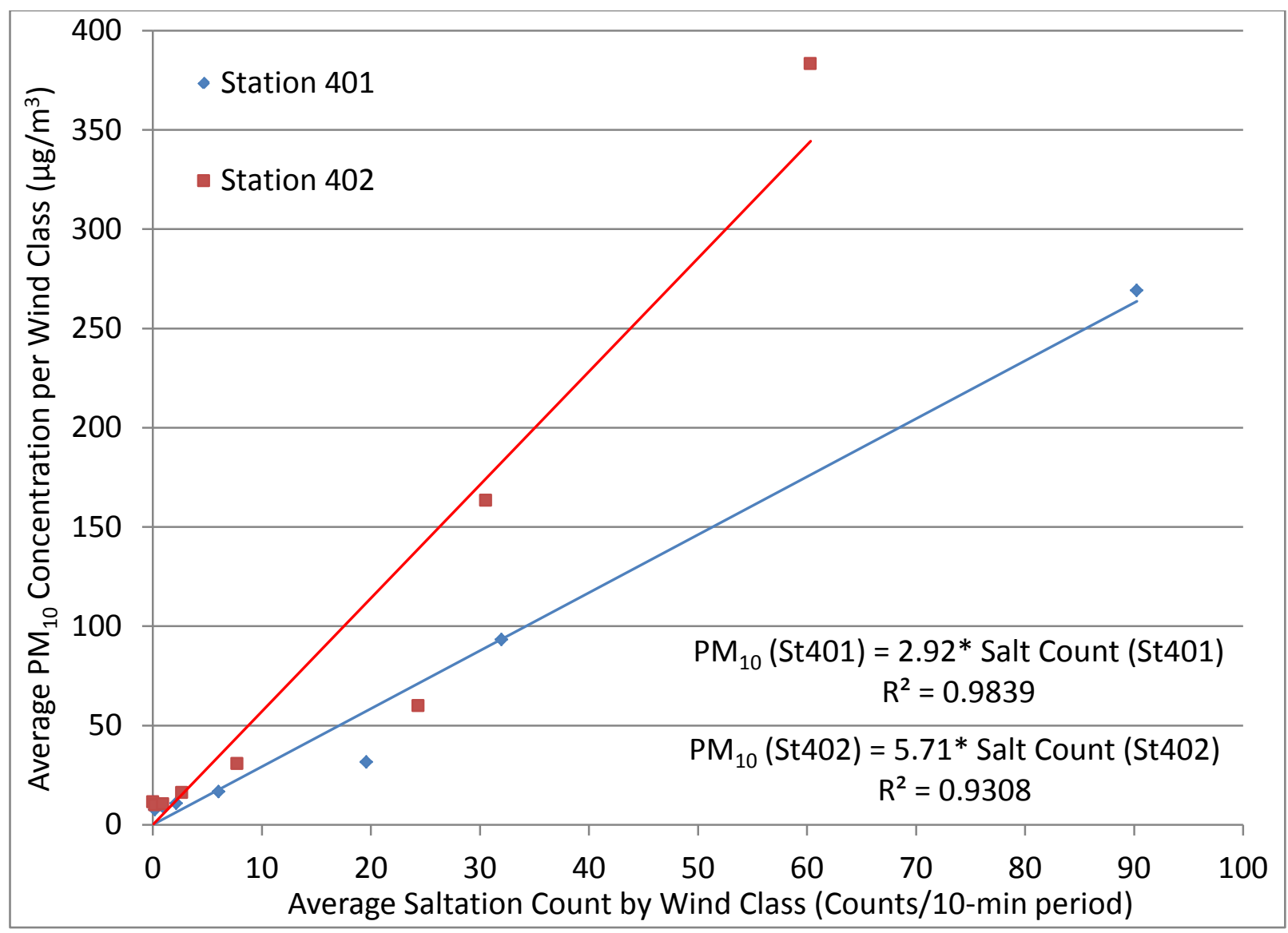

Figure 15. Regression of $\mathrm{PM}_{10}$ concentration against saltation counts shows a strong correlation between the two measurements.

\section{OBSERVATIONS OF SOIL TRANSPORT BY SUSPENSION}

Table 10 summarizes wind speed and the corresponding $\mathrm{PM}_{10}$ concentration by wind-speed class for Stations 400, 401, and 402. Approximately $90 \%$ of the time, the wind speed at all three stations is below $24 \mathrm{~km} / \mathrm{hr}(15 \mathrm{mph})$ and the corresponding average $\mathrm{PM}_{10}$ concentrations are below $15 \mu \mathrm{g} / \mathrm{m}^{3}$. Only 10 percent of the time is wind speed above $24 \mathrm{~km} / \mathrm{hr}$ (15 mph), and even then, although $\mathrm{PM}_{10}$ concentrations increase as wind speed increases, the $\mathrm{PM}_{10}$ concentrations remain fairly low until winds exceed about $40 \mathrm{~km} / \mathrm{hr}$ (25 mph) (less than 1 percent of the time). At Station 400, $\mathrm{PM}_{10}$ concentrations exceed $50 \mu \mathrm{g} / \mathrm{m}^{3}$ for winds in excess of $48 \mathrm{~km} / \mathrm{hr}$ (30 mph); whereas, at Stations 401 and 402, $\mathrm{PM}_{10}$ concentrations greater than $90 \mu \mathrm{g} / \mathrm{m}^{3}$ are associated with winds in excess of $48 \mathrm{~km} / \mathrm{hr}$ (30 mph). However, high wind and correspondingly high $\mathrm{PM}_{10}$ events are relatively rare and generally last for only short periods of time. Wind speed exceeds $48 \mathrm{~km} / \mathrm{hr}$ (30 mph) only 0.03 percent ( $<3 \mathrm{hr}$ ) of the year at Station 400, 0.16 percent (approximately $14 \mathrm{hr}$ ) of the year at Station 401, and 0.12 percent $(<11 \mathrm{hr})$ of the year at Station 402. 
Table 10. Summary of wind and PM10 data for Stations 400, 401, and 402 for calendar year 2012.

\begin{tabular}{|c|c|c|c|c|c|}
\hline $\begin{array}{l}\text { Wind Speed } \\
\text { Class (mph) }\end{array}$ & Duration (hours) & Frequency (\%) & $\begin{array}{c}\text { Cumulative } \\
\text { Frequency (\%) }\end{array}$ & $\begin{array}{l}\text { Average Wind } \\
\text { Speed (mph) }\end{array}$ & $\mathrm{PM}_{10}\left(\mu \mathrm{g} / \mathrm{m}^{3}\right)$ \\
\hline \multicolumn{6}{|l|}{ Station 400} \\
\hline $0-5$ & 3450.0 & 39.28 & 39.28 & 3.2 & 17.89 \\
\hline $5-10$ & 3065.7 & 34.90 & 74.18 & 7.2 & 13.45 \\
\hline $10-15$ & 1418.7 & 16.15 & 90.33 & 12.2 & 14.30 \\
\hline $15-20$ & 583.3 & 6.64 & 96.97 & 17.1 & 24.23 \\
\hline $20-25$ & 226.2 & 2.57 & 99.54 & 22.1 & 35.98 \\
\hline $25-30$ & 37.5 & 0.43 & 99.97 & 26.5 & 53.16 \\
\hline $30-35$ & 2.7 & 0.03 & 100.00 & 31.4 & 51.39 \\
\hline$>35$ & 0.0 & 0.00 & 100.00 & & \\
\hline Total & \multicolumn{2}{|l|}{8784.0} & \multicolumn{2}{|c|}{ Annual Average } & 16.8 \\
\hline \multicolumn{6}{|l|}{ Station 401} \\
\hline $0-5$ & 3783.3 & 43.07 & 43.07 & 2.9 & 11.5 \\
\hline $5-10$ & 2729.7 & 31.07 & 74.14 & 7.1 & 7.7 \\
\hline $10-15$ & 1298.7 & 14.78 & 88.93 & 12.3 & 8.7 \\
\hline $15-20$ & 625.5 & 7.12 & 96.05 & 17.1 & 10.8 \\
\hline $20-25$ & 268.7 & 3.06 & 99.11 & 22.0 & 16.7 \\
\hline $25-30$ & 64.8 & 0.74 & 99.85 & 26.6 & 31.5 \\
\hline $30-35$ & 12.8 & 0.15 & 99.99 & 31.6 & 93.9 \\
\hline$>35$ & 0.7 & 0.01 & 100.00 & 36.4 & 269.2 \\
\hline Total & \multicolumn{2}{|l|}{8784.2} & \multicolumn{2}{|c|}{ Annual Average } & 10.3 \\
\hline \multicolumn{6}{|l|}{ Station 402} \\
\hline $0-5$ & 4439.5 & 50.54 & 50.54 & 2.9 & 11.5 \\
\hline $5-10$ & 2235.2 & 25.45 & 75.99 & 7.0 & 10.0 \\
\hline $10-15$ & 1218.5 & 13.87 & 89.86 & 12.1 & 10.5 \\
\hline $15-20$ & 584.8 & 6.66 & 96.52 & 17.0 & 16.1 \\
\hline $20-25$ & 239.8 & 2.73 & 99.25 & 21.7 & 30.7 \\
\hline $25-30$ & 55.7 & 0.63 & 99.88 & 26.2 & 59.9 \\
\hline $30-35$ & 10.0 & 0.11 & 99.99 & 30.6 & 163.4 \\
\hline$>35$ & 0.5 & 0.01 & 100.00 & 35.0 & 383.3 \\
\hline Total & \multicolumn{2}{|l|}{8784.0} & \multicolumn{2}{|c|}{ Annual Average } & 12.3 \\
\hline
\end{tabular}


Various wind speeds occur with similar frequency at all stations (Figure 16). Light winds ( 0 to $8 \mathrm{~km} / \mathrm{hr}$ [0 to $5 \mathrm{mph}$ ]) are most common. Wind speeds in excess of $24 \mathrm{~km} / \mathrm{hr}$ (15 mph) occur only about 10 percent of the time and wind speeds in excess of $32 \mathrm{~km} / \mathrm{hr}$ (20 mph) occur only about five percent of the time.

At stations 401 and 402, the average $\mathrm{PM}_{10}$ concentration increases in an approximately exponential pattern with linear increases in wind speed (Figure 17). Station 400 shows a similar pattern through wind speeds of about $40 \mathrm{~km} / \mathrm{hr}$ ( $25 \mathrm{mph}$ ); however, the $\mathrm{PM}_{10}$ concentration at Station 400 did not increase as the wind speed increased from about 40 to about $48 \mathrm{~km} / \mathrm{hr}$ (25 to $30 \mathrm{mph}$ ). As noted above, wind speed at Station 400 exceeded $30 \mathrm{mph}$ only about 0.03 percent of the time $(<3 \mathrm{hr})$ and never reached the maximum speeds observed at Stations 401 and 402. In addition to the difference in maximum wind speeds, other meteorological conditions or local station characteristics are likely to contribute to the reduced $\mathrm{PM}_{10}$ concentration during high winds at Station 400. For example, Station 400, located on the south side of the ROC, is shielded from northwest winds by buildings and the open ground surrounding the station is covered with gravel for use as a storage yard.

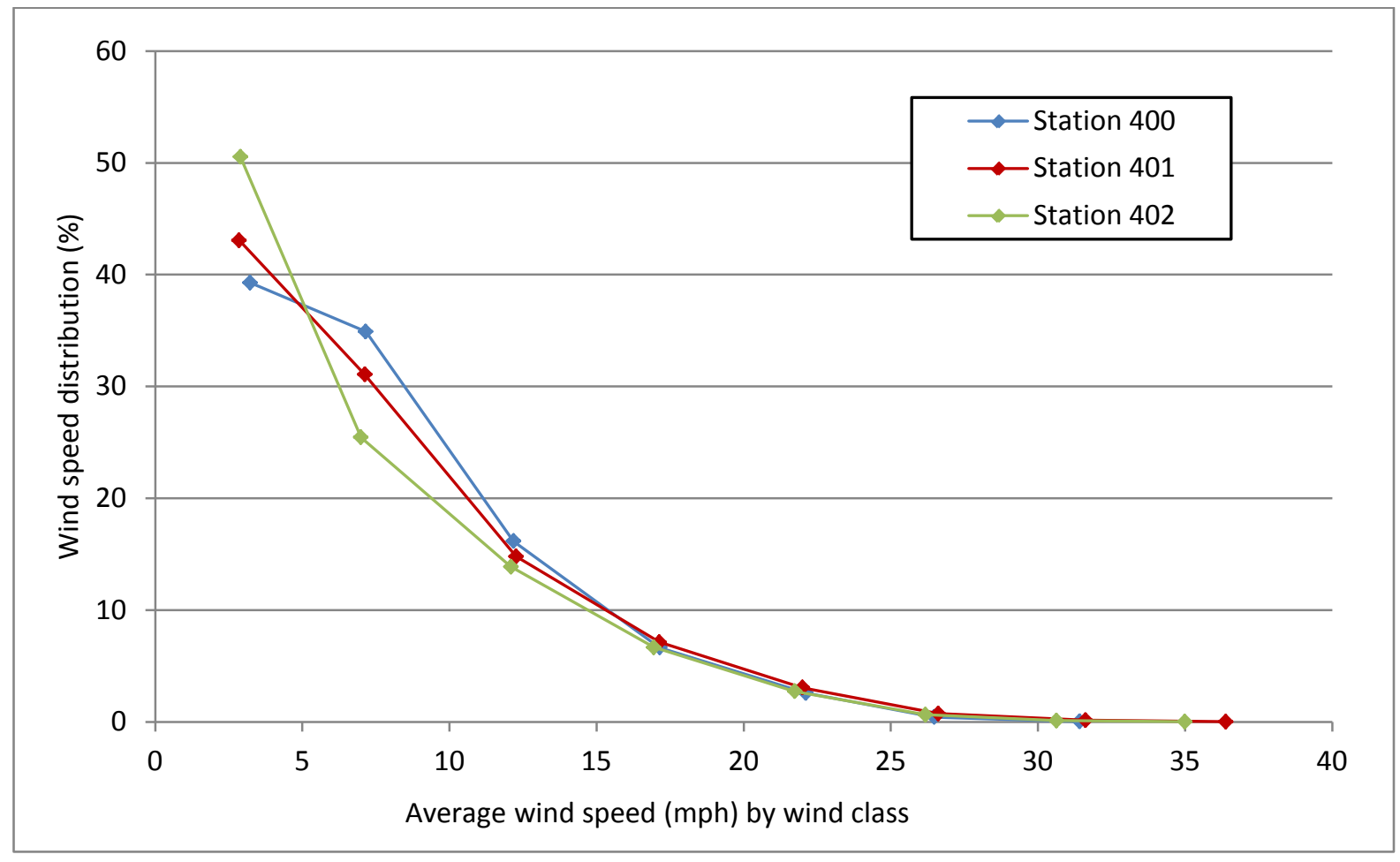

Figure 16. Wind speed frequency by wind class for Stations 400,401, and 402 for CY2012. The portion of time wind speed falls within a given class is plotted against the average wind speed for that class. 


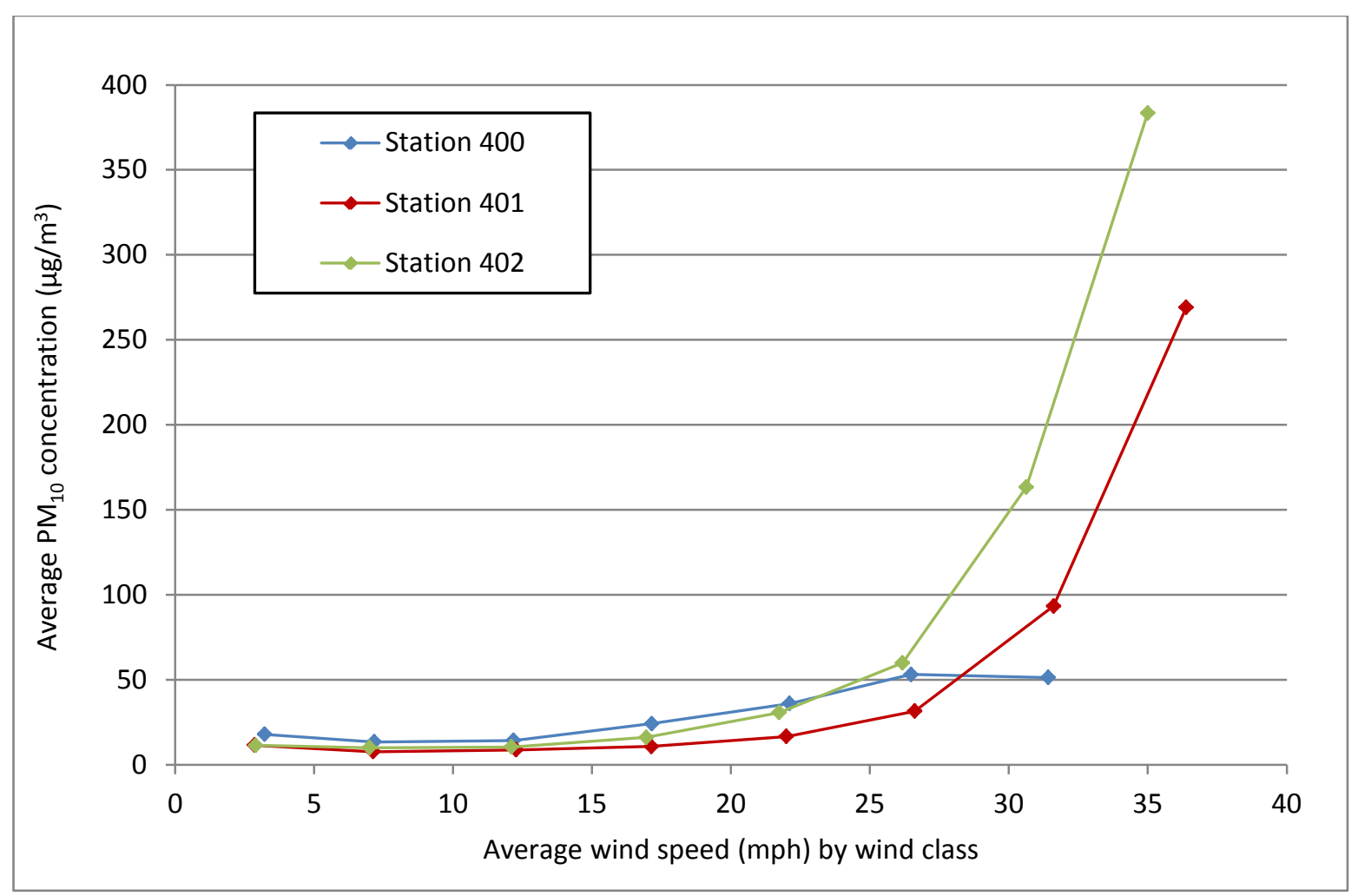

Figure 17. $\mathrm{PM}_{10}$ trends as a function of wind speed for stations 400, 401, and 402 for CY2012.

Even though the $\mathrm{PM}_{10}$ concentration increases dramatically at high wind speeds, this does not imply that large volumes of soil material are moving. The wind speeds necessary to generate the higher $\mathrm{PM}_{10}$ concentrations occur less than about five percent of the time.

Figures 18 and 19 illustrate a high wind and high $\mathrm{PM}_{10}$ event that occurred at Stations 401 and 402 on February 25, 2012. At Station 401, the maximum hourly wind speed (red trace) reached almost $72 \mathrm{~km} / \mathrm{hr}(45 \mathrm{mph}$ ) (Figure 18) and the steady average speed (blue trace) reached around $48 \mathrm{~km} / \mathrm{hr}(30 \mathrm{mph})$. The average wind speed for most of the event was above $32 \mathrm{~km} / \mathrm{hr}$ (20 mph) but the $\mathrm{PM}_{10}$ concentration (olive colored trace) remained below $25 \mu \mathrm{g} / \mathrm{m}^{3}$ for most of the event. It was only during the maximum wind speed that the $\mathrm{PM}_{10}$ concentration exceeded $100 \mu \mathrm{g} / \mathrm{m}^{3}$, and the $\mathrm{PM}_{10}$ concentration remained above $50 \mu \mathrm{g} / \mathrm{m}^{3}$ for no more than 30 minutes. At Station 402, the maximum hourly wind speed (red trace) reached just over $64 \mathrm{~km} / \mathrm{hr}$ (40 mph) (Figure 19) and the steady average speed (blue trace) topped out at about $43 \mathrm{~km} / \mathrm{hr}(27 \mathrm{mph})$. The average wind speed for most of the event was above $32 \mathrm{~km} / \mathrm{hr}$ (20 mph) but the $\mathrm{PM}_{10}$ concentration (olive colored trace) remained below $25 \mu \mathrm{g} / \mathrm{m}^{3}$ most of the time. The maximum $\mathrm{PM}_{10}$ concentration at Station 402 was nearly twice the maximum observed at Station 401. Additionally, the $\mathrm{PM}_{10}$ concentration at Station 402 remained above $50 \mu \mathrm{g} / \mathrm{m}^{3}$ for several hours. Differences between the $\mathrm{PM}_{10}$ concentrations at Stations 401 and 402 indicate either local differences in soil conditions or soil disturbance. Station 402 at Clean Slate 1 is approximately $500 \mathrm{~m}$ (1600 ft) south of a well-used dirt road where $\mathrm{PM}_{10}$ particles would likely be readily available. Additionly, Station 402 appears to be located on a surface likely to consist of finer soil particles than at Station 401. The monitoring data indicate that wind events like this occur approximately 
once per month during most of the year and are most likely to happen between 11:00 AM and 3:00 PM when winds are usually at their strongest.

The secondary rise in $\mathrm{PM}_{10}$ seen at about 1:00 AM on February 26, 2012 (Figures 18 and 19) may be a dust "cloud" generated at another up-wind location and transported past the sensors at Stations 401 and 402. This interpretation is suggested because the peak appears as a broad, smooth curve, indicative of a well-mixed air mass, rather than a series of erratic peaks.

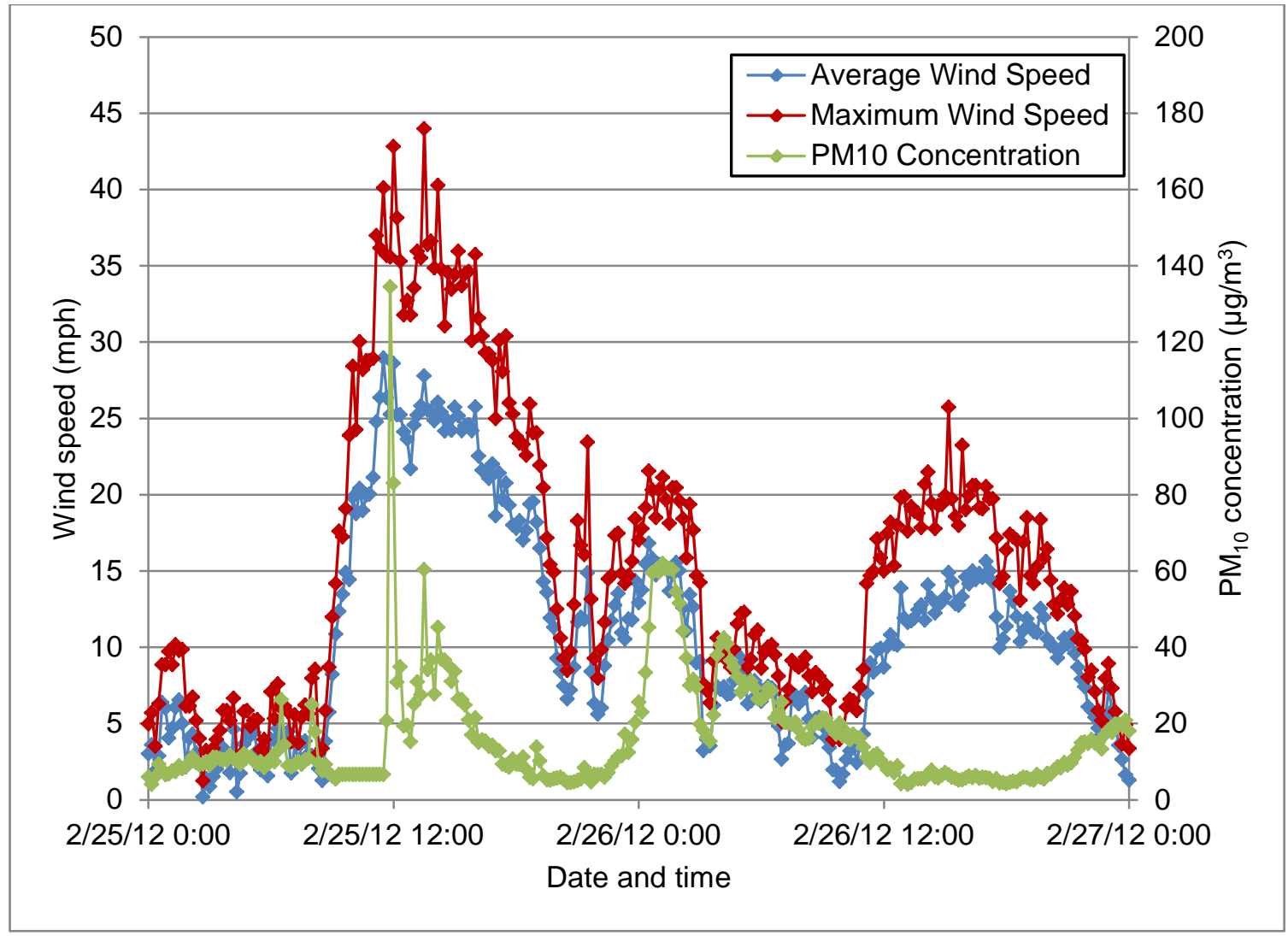

Figure 18. An illustrative high wind/high $\mathrm{PM}_{10}$ event observed at Station 401 on February 25 and 26, 2012. 


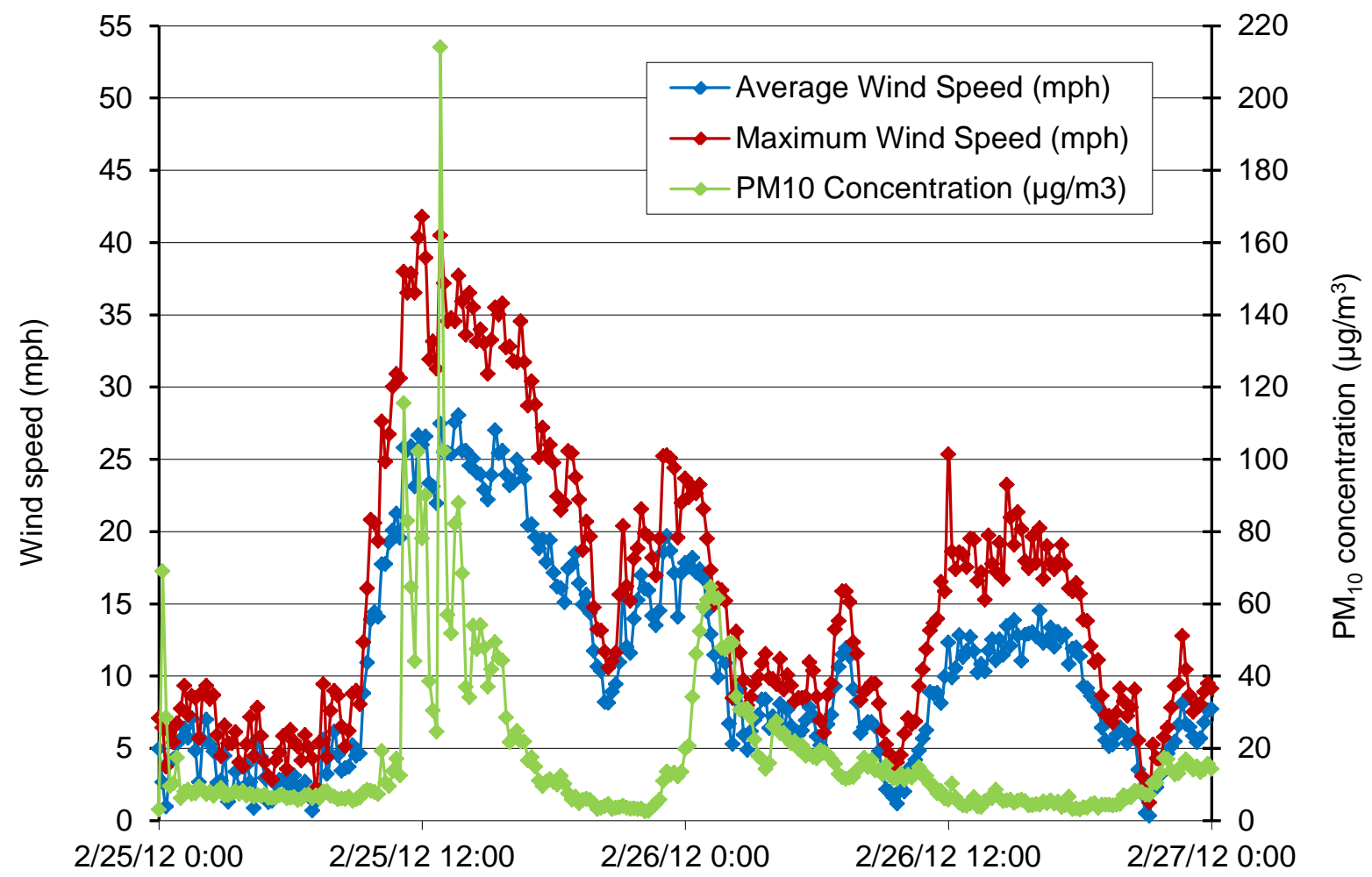

Date and time

Figure 19. An illustrative high wind/high $\mathrm{PM}_{10}$ event observed at Station 402 on February 25 and 26, 2012.

This wind and dust event at Stations 401 and 402 illustrates the impact of high wind speed on the $\mathrm{PM}_{10}$ concentration and soil migration. Observations of this event clearly suggest that the relationship between wind speed and dust concentration is very non-linear. The non-linear relationship is indicated because a relatively small, 20 percent, increase in average wind speed (from 40 to $48 \mathrm{~km} / \mathrm{hr}$ [25 to $30 \mathrm{mph}$ ]) may result in a significant increase in $\mathrm{PM}_{10}$ (from $20 \mu \mathrm{g} / \mathrm{m}^{3}$ to $100 \mu \mathrm{g} / \mathrm{m}^{3}$ ). Additionally, the $\mathrm{PM}_{10}$ concentration may drop off sharply although the wind speed continues to be high. This condition occurs because the $\mathrm{PM}_{10}$ supply is source limited; all available dust is transported during the early moments of a wind event and little additional dust is available until other phenomena again break up the soil surface. Factors other than wind speed, such as soil moisture content and relative humidity, may affect the $\mathrm{PM}_{10}$ concentration generated by wind events. 


\section{CONCLUSIONS}

1. Higher gross alpha and gross beta concentrations were observed at Station 400 in the SNL Range Operations Center than at Stations 401 (Clean Slate 3) and 402 (Clean Slate 1). This difference is believed to be due to the different filter material used in the sampler collectors. The glass-fiber filters used at Station 400 have smaller pore size than the cellulose-fiber filters used at the other two stations.

2. Gamma exposure measurements collected using pressurized ion chambers (PICs) resulted in similar values at Stations 400 (ROC) and 402 (Clean Slate 1); the average exposure at these stations are in the range of the mean $+/$ - one standard deviation. The observed average gamma exposure at Station 401 (Clean Slate 3) is 15 to 17 percent higher than the average exposure at Stations 400 and 402 . The average gamma exposure at the TTR observations stations is in the upper range to slightly higher than values observed at CEMP stations surrounding the TTR.

3. Meteorological observations at all three TTR observations stations are generally similar. Wind patterns indicate that winds are principally from two directions: south to southeast and northwest. During 2012, precipitation was a notable exception to the pattern of similarity. A single storm event in mid-July produced approximately $12.7 \mathrm{~mm}$ at Station 400 but 1.6 times that much at Station 401 and 5 times that much rainfall at Station 402.

4. Soil movement by saltation was consistent at Stations 401 and 402 for winds of less than about $48 \mathrm{~km} / \mathrm{hr}$ (30 mph). At wind speeds in the 56 to $64 \mathrm{~km} / \mathrm{hr}$ (35 to $40 \mathrm{mph}$ ) range the average observed saltation count was 1.5 times greater at Station 401 (Clean Slate 3) than at Station 402 (Clean Slate 1). This difference likely reflects a difference in the soil particle size range present at the ground surface. Station 402 is located near the playa and only about 500 m (1640 ft) from a frequently traveled dirt road while Station 401 is located on an interfluve, a slightly elevated surface between drainage channels. There is no saltation sensor at Station 400 .

5. Movement of inhalable soil particles by suspension showed slight differences between the three stations. At wind speeds below $32 \mathrm{~km} / \mathrm{hr}$ (20 mph), the concentration of suspended $\mathrm{PM}_{10}$ was about the same at all stations. Between 32 and $48 \mathrm{~km} / \mathrm{hr}$ (20 and $30 \mathrm{mph}$ ), suspended $\mathrm{PM}_{10}$ was greater at Stations 400 (ROC) and 402 (Clean Slate 1) than at Station 401 (Clean Slate 3). Above $48 \mathrm{~km} / \mathrm{hr}$ (30 mph), no change was observed in the $\mathrm{PM}_{10}$ concentration at Station 400 but the concentration at Station 402 continued to be about 1.5 times the concentration at Station 401. Differences between suspended $\mathrm{PM}_{10}$ at Stations 401 and 402 is likely because 402 is located near the playa and is only about $500 \mathrm{~m}$ from a frequently traveled dirt road.

6. During 2012, high wind events produced different $\mathrm{PM}_{10}$ suspension concentration patterns. At Station 401 (Clean Slate 3), the dust concentration peaked quickly and then subsided although wind speed continued to be high. At Station 402 (Clean Slate 1), the dust concentration peaked repeatedly in response to wind speed peaks. It is likely that the $\mathrm{PM}_{10}$ availability at Station 401 (Clean Slate 3) is less than the $\mathrm{PM}_{10}$ availability at Station 402 
(Clean Slate I). This is again believed to be due to the playa sediments and the near-by dirt road. The resulting affect is that windblown dust patterns at Station 401 (Clean Slate 3) are defined and controlled by a limited availability of dust on the soil surface.

\section{RECOMMENDATIONS}

1. The sample filters at all three stations should be standardized. Additionally, a parallel collection system should be installed at Station 400 to permit use of both glass and cellulose fiber filters in order to establish a regression relationship that can be used to adjust the data and permit direct comparison of radiological measurements at all three stations.

2. It would be advisable to perform a size analysis of a representative sample of the soil material on the surface at each of the monitoring stations. This would facilitate characterization of the sites and differences in their natural condition. This information would in turn aid interpretation of the saltation and dust transport observations.

3. With approximately four years of observations available at Stations 400 and 401 and a year of observations available for Station 402, a multi-year, period-of-record analysis of the radiological and airborne dust conditions is appropriate. 


\section{REFERENCES}

Dick, J.L., J.D.Shreve, and J.S. Iveson. 1963. Operation Roller Coaster, Interim Summary Report (II). POIR-2500 (Volume 1) Defense Atomic Support Agency, Washington, D.C.

Duncan, D., W Forston, and R Sanchez. 2000. 1999 Annual Site Environmental Report Tonopah Test Range, Nevada. SAND2000-2229, Sandia National laboratories, Albuquerque, NM.

EG\&G. 1979. An Aerial Radiological Survey of Clean Slates 1, 2, and 3, and Double Track, Test Range. EGG-1183-1737, Energy Measurement Group, EG\&G, Las Vegas, NV.

Engelbrecht, J.P, I.G. Kavouras, D. Campbell, S.A. Campbell, S. Kohl, D. Shafer, 2008. Yucca Mountain Environmental Monitoring System Initiative, Air Quality Scoping Study for Tonopah Airport, Nye County, Nevada, Letter report DOE/NV/26383LTR2008-04.

NSTec. 2012. Nevada National Security Site Environmental Report 2011. DOE/NV/25946-1604, prepared by National Security Technologies, LLC for the US Department of Energy, National Nuclear Security Administration, Nevada Site Office.

SNL, 2011. 2010 Annual Site Environmental Report for Tonopah Test Range, Nevada and Kauai Test Facility, Hawaii. SAND2011-5616P, Sandia National Laboratories, September 2011.

Johnson, W. G. and S. R. Edwards. 1996. A historical evaluation of Operation Roller Coaster, Stonewall and Cactus Flats, Nellis Air Force Range and Tonopah Test Range, Nye County, Nevada. NTS Project \#9649MA, Historic Evaluation Short Report \#SR090996-1, prepared by Desert Research Institute for US Department of Energy, Nevada Operations Office, Las Vegas, Nevada.

Proctor, AE, and TJ Hendricks, 1995. An aerial radiological survey of the Tonopah Test Range including Clean Slate 1, 2, 3, Roller Coaster, Decontamination area Cactus Springs Ranch Target areas Central Nevada. EGG 11265-1145, The Remote Sensing Laboratory, EG\&G Energy Measurements prepared for the US Department of Energy.

SNL. 2012. Calendar Year 2011 Annual Site Environmental Report for Tonopah Test Range, Nevada and Kauai Test Facility, Hawaii. SAND2012-7341P, Sandia National laboratories, Albuquerque, NM.

UNSCEAR. 2000. Sources and effects of ionizing radiation, Annex B: Exposures from natural radiation sources. United Nations Scientific Committee on the Effects of atomic Radiation. Available May 6, 2013 at:

http://www.unscear.org/unscear/publications/2000_1.html. 
APPENDIX A: METEOROLOGICAL AND ENVIRONMENTAL DATA

OBSERVED AT TTR AIR MONITORING STATIONS 400, 401, AND 402

DURING CY2012 


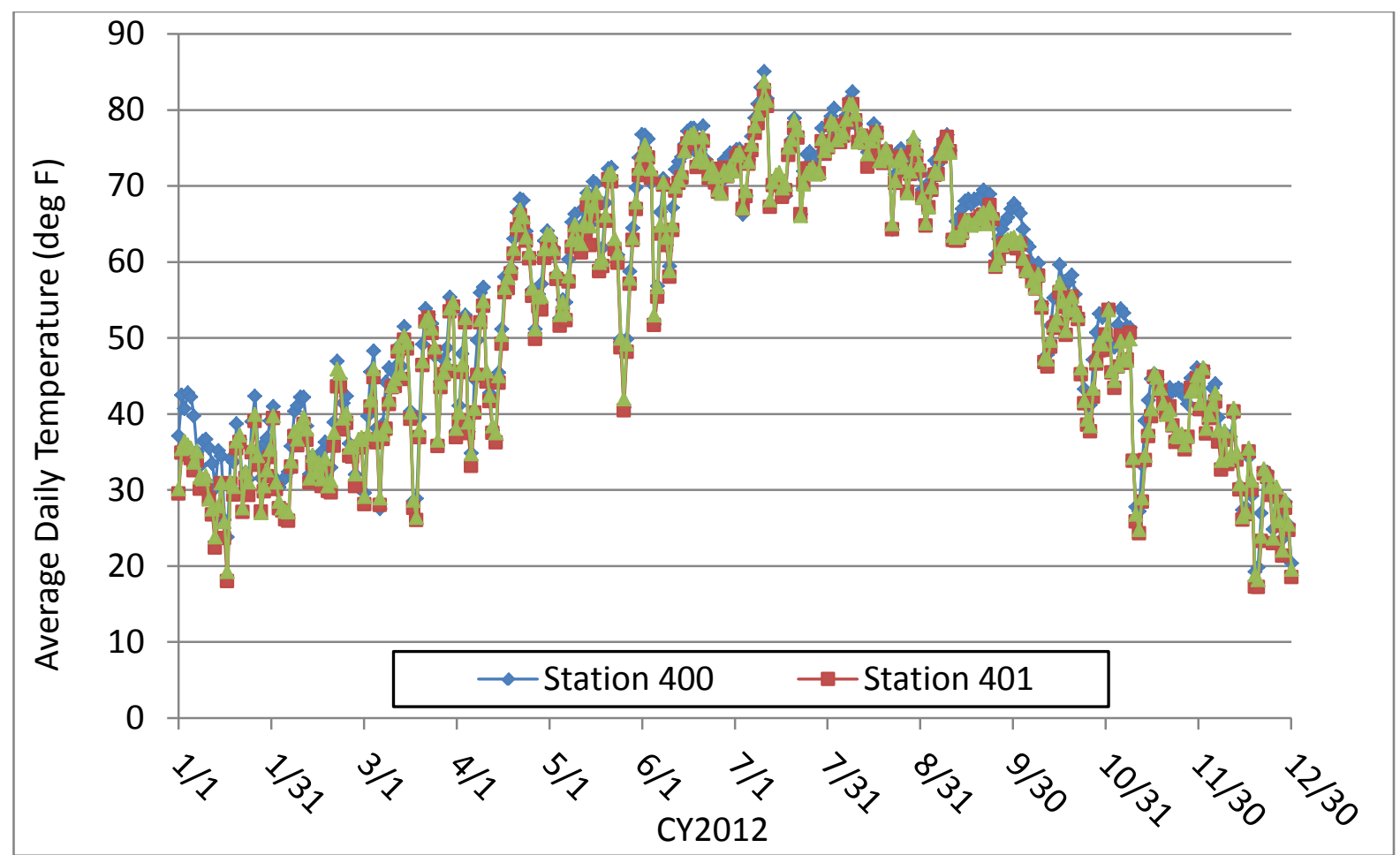

Figure A-1. Average daily air temperature $\left({ }^{\circ} \mathrm{F}\right)$ for TTR air monitoring Stations 400, 401, and 402 during CY2012.

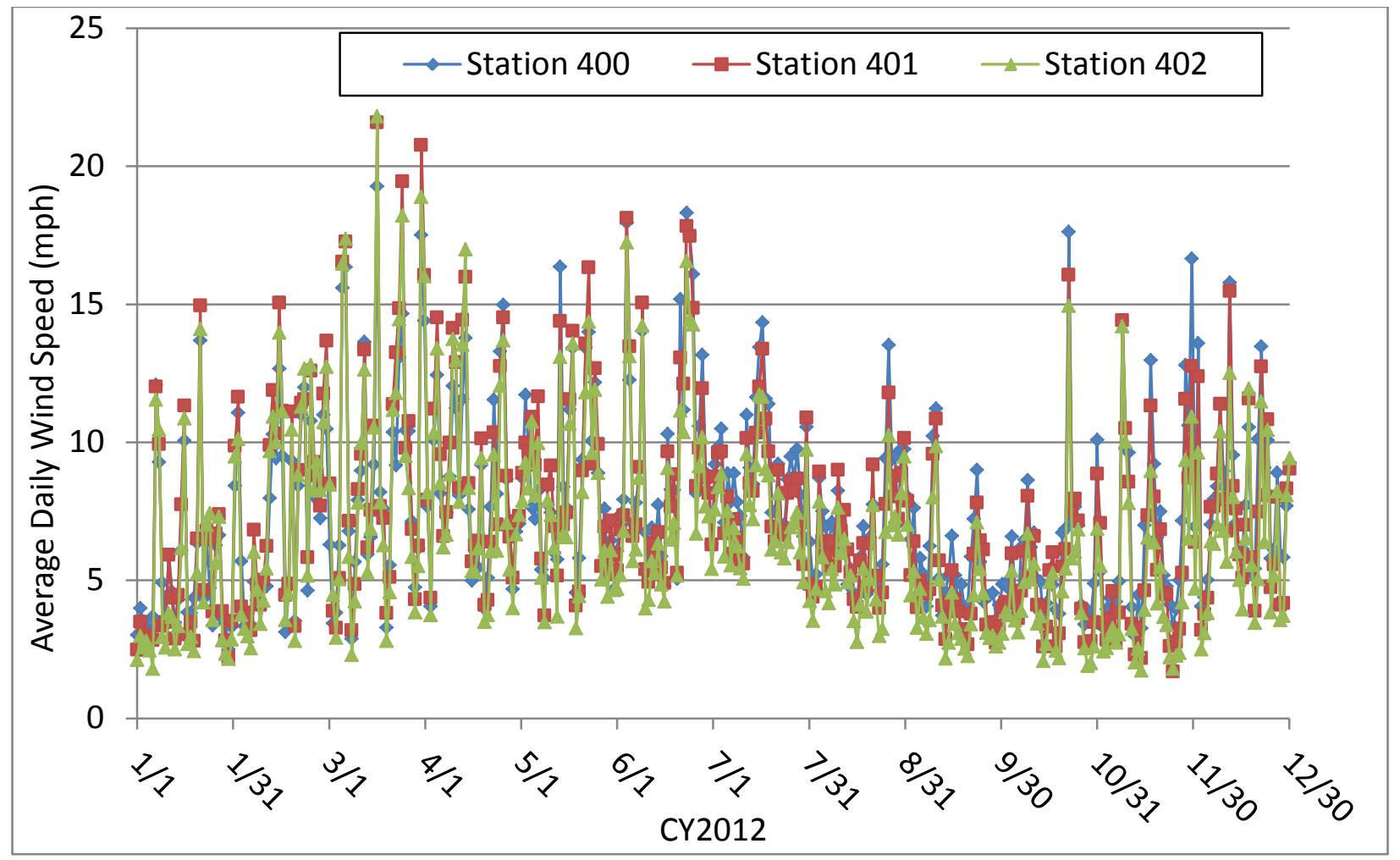

Figure A-2. Average daily wind speed (mph) at TTR air monitoring Stations 400, 401, and 402 during CY2012. 


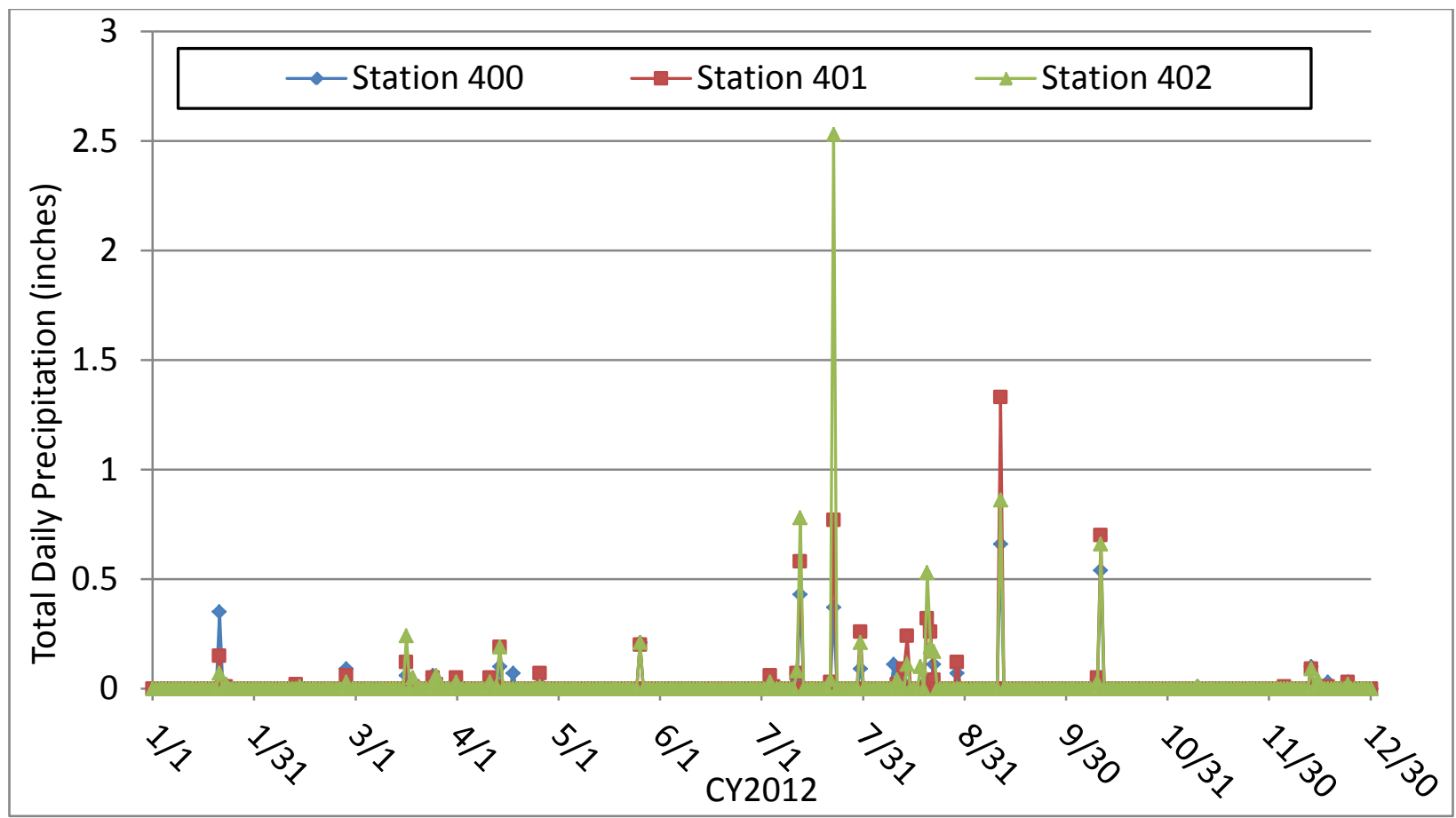

Figure A-3. Total daily precipitation amounts for TTR air monitoring Stations 400, 401, and 402 during CY2012.

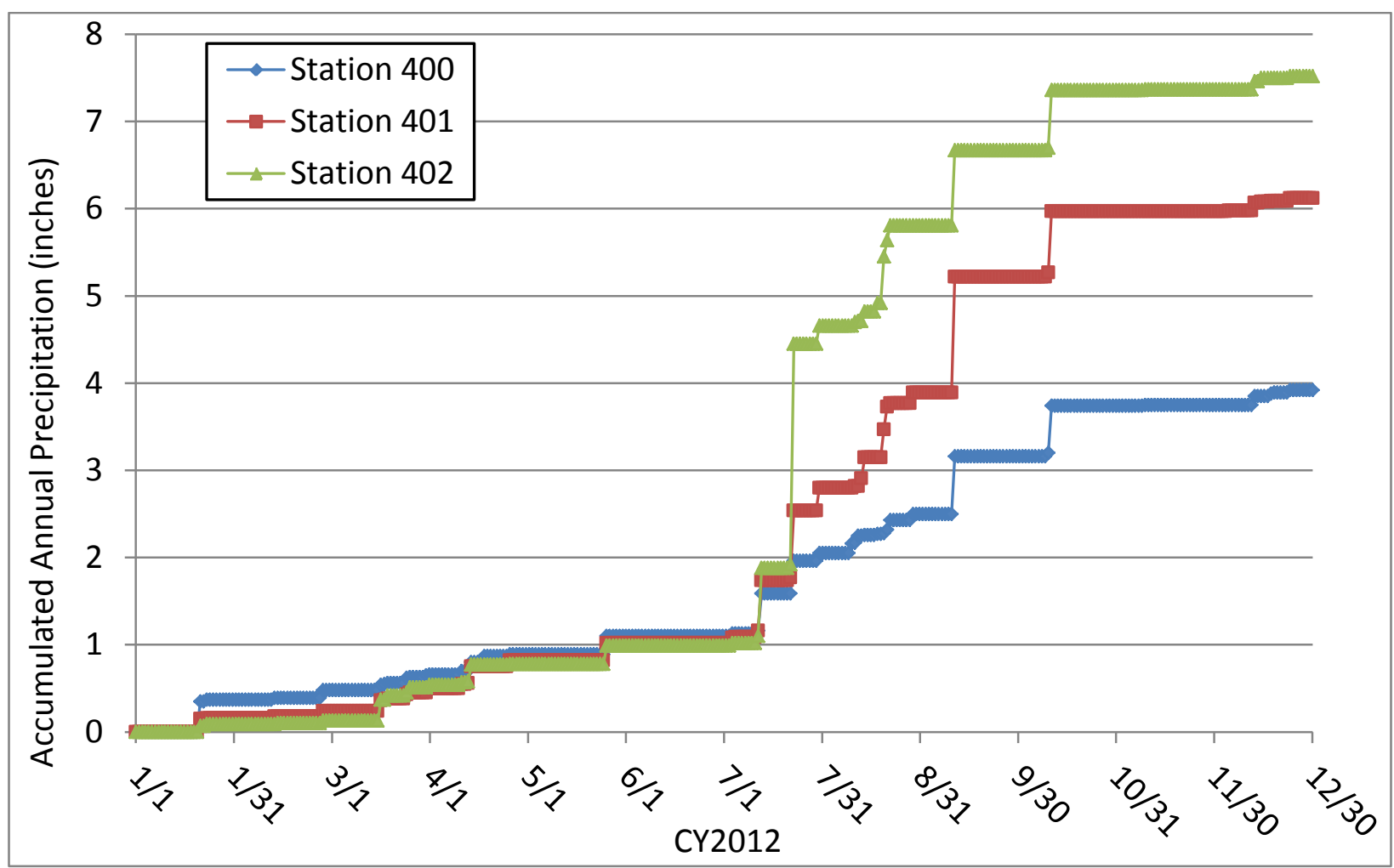

Figure A-4. Cumulative annual precipitation for TTR air monitoring Stations 400, 401, and 402 during CY2012.

34 


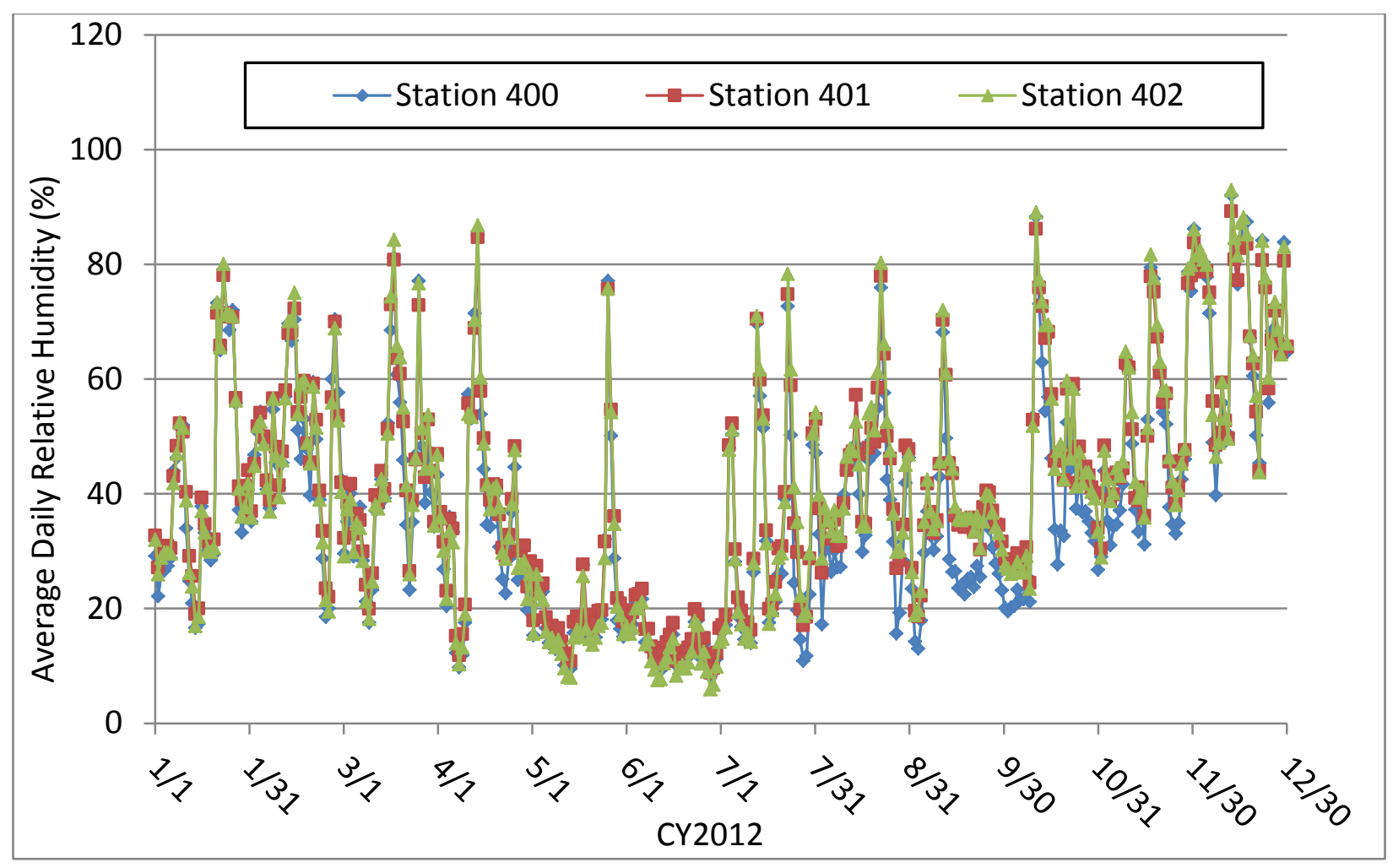

Figure A-5. Average daily relative humidity for TTR air monitoring Stations 400, 401, and 402 during CY2012.

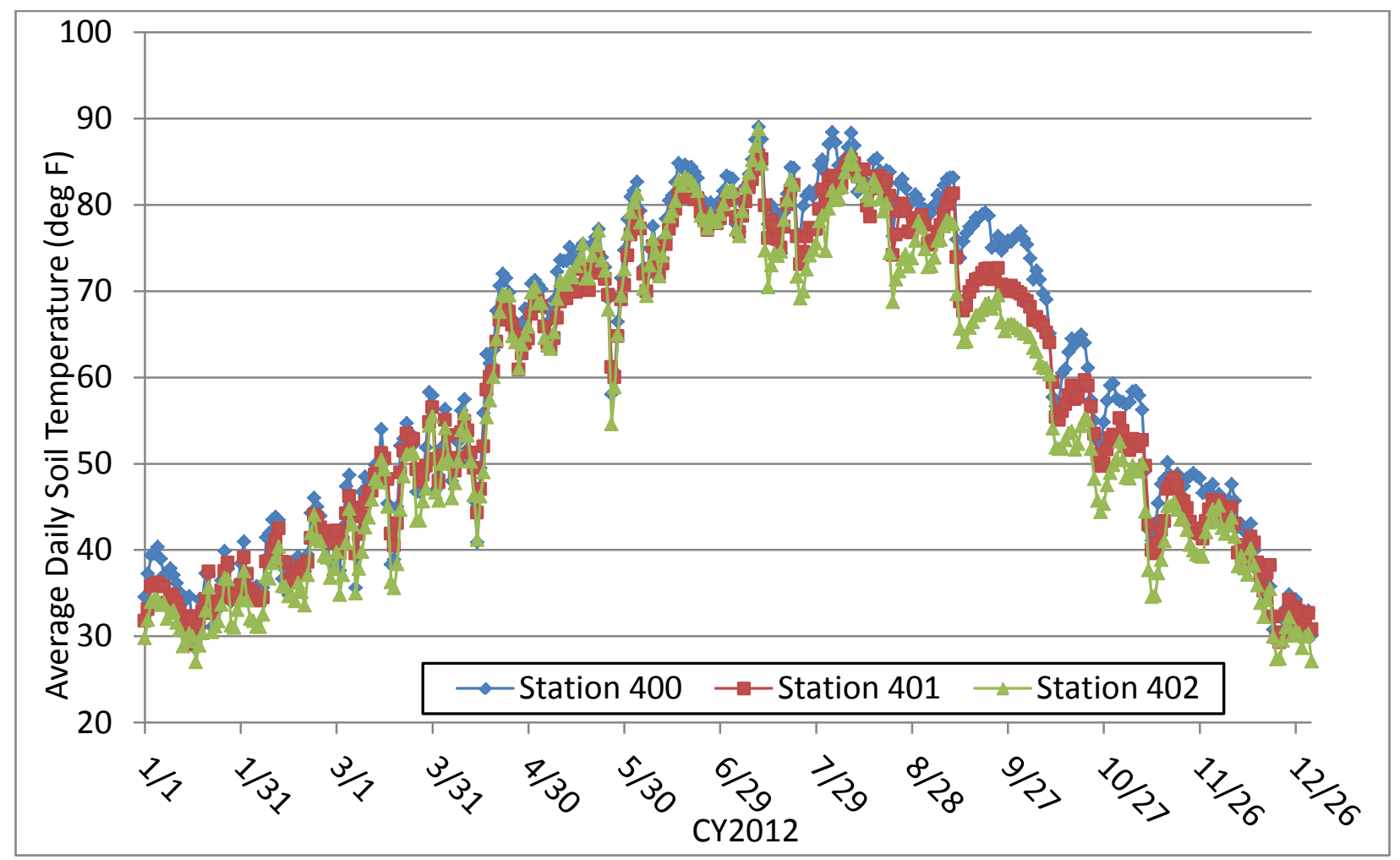

Figure A-6. Average daily soil temperature at TTR air monitoring Stations 400, 401, and 402 during CY2012. 


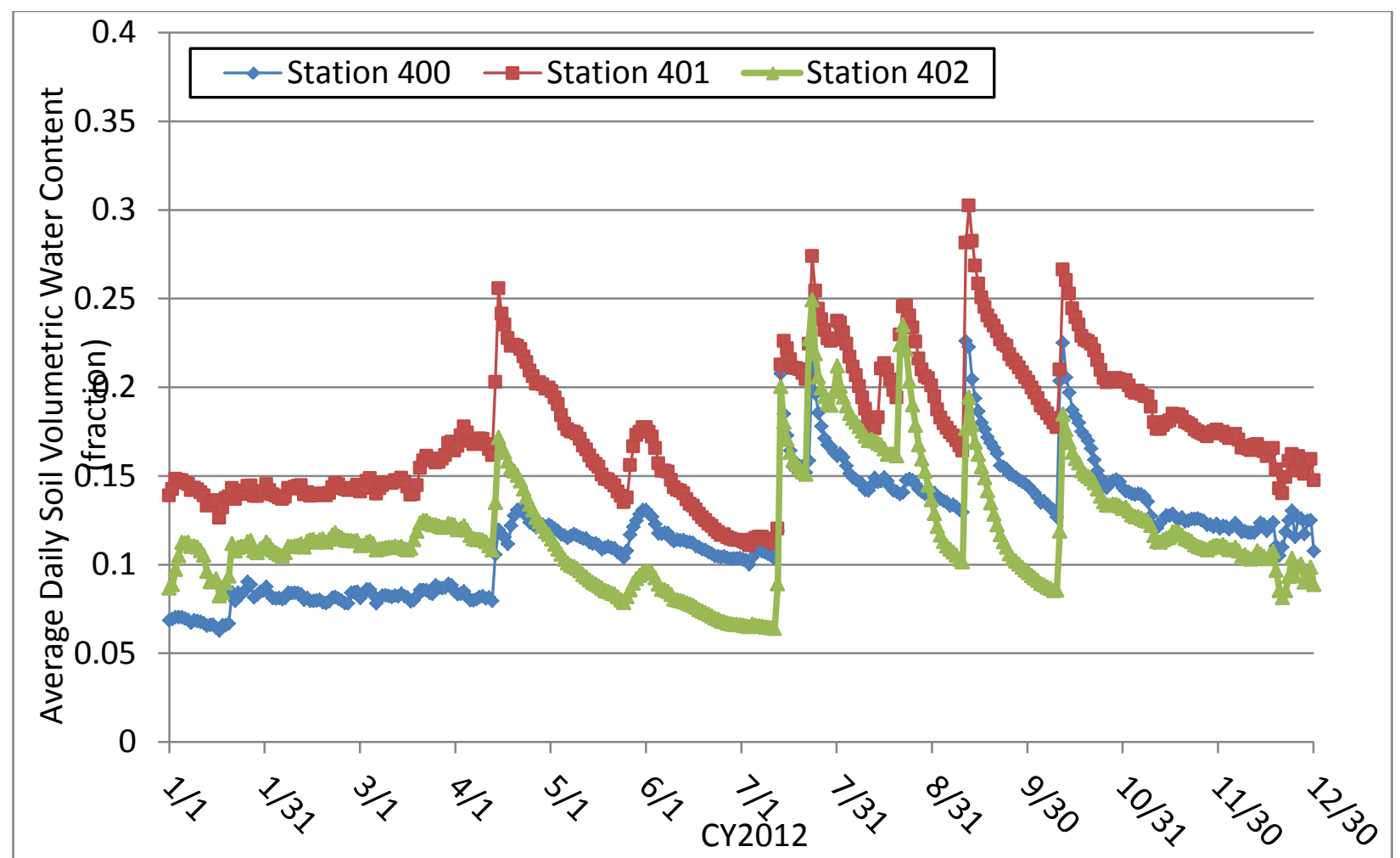

Figure A-7. Average daily volumetric soil water content at TTR air monitoring Stations 400, 401, 402 during CY2012.

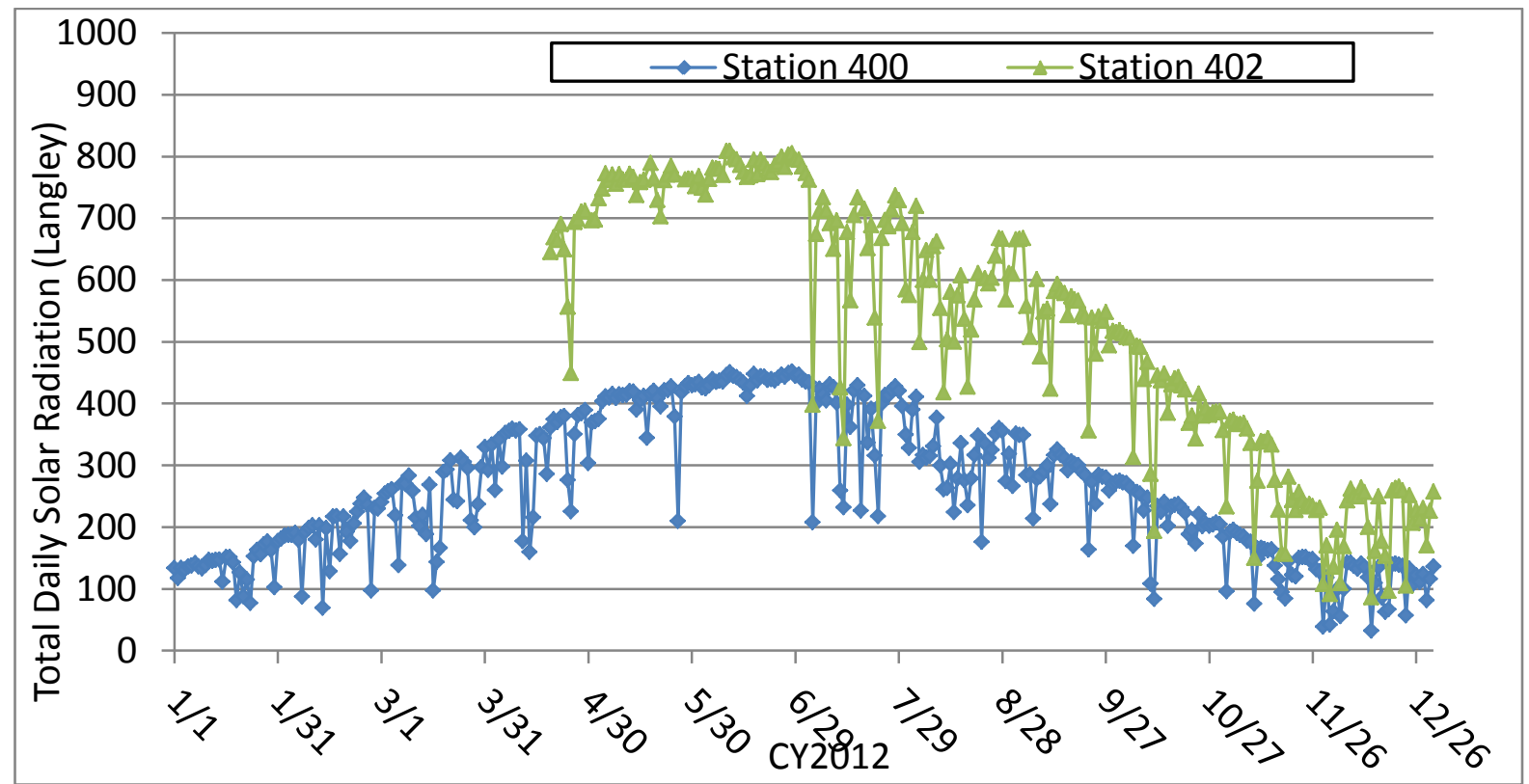

Figure A-8. Total daily solar radiation (Langley) for TTR air monitoring Stations 400 and 402 during CY2012. Solar radiation data from one of these stations is believed to be incorrectly calculated due to use of improper scaling parameters in the data collection program. This issue is being investigated but had not been resolved when this report was submitted. The problem will be resolved before subsequent reports of this monitoring effort are completed. 


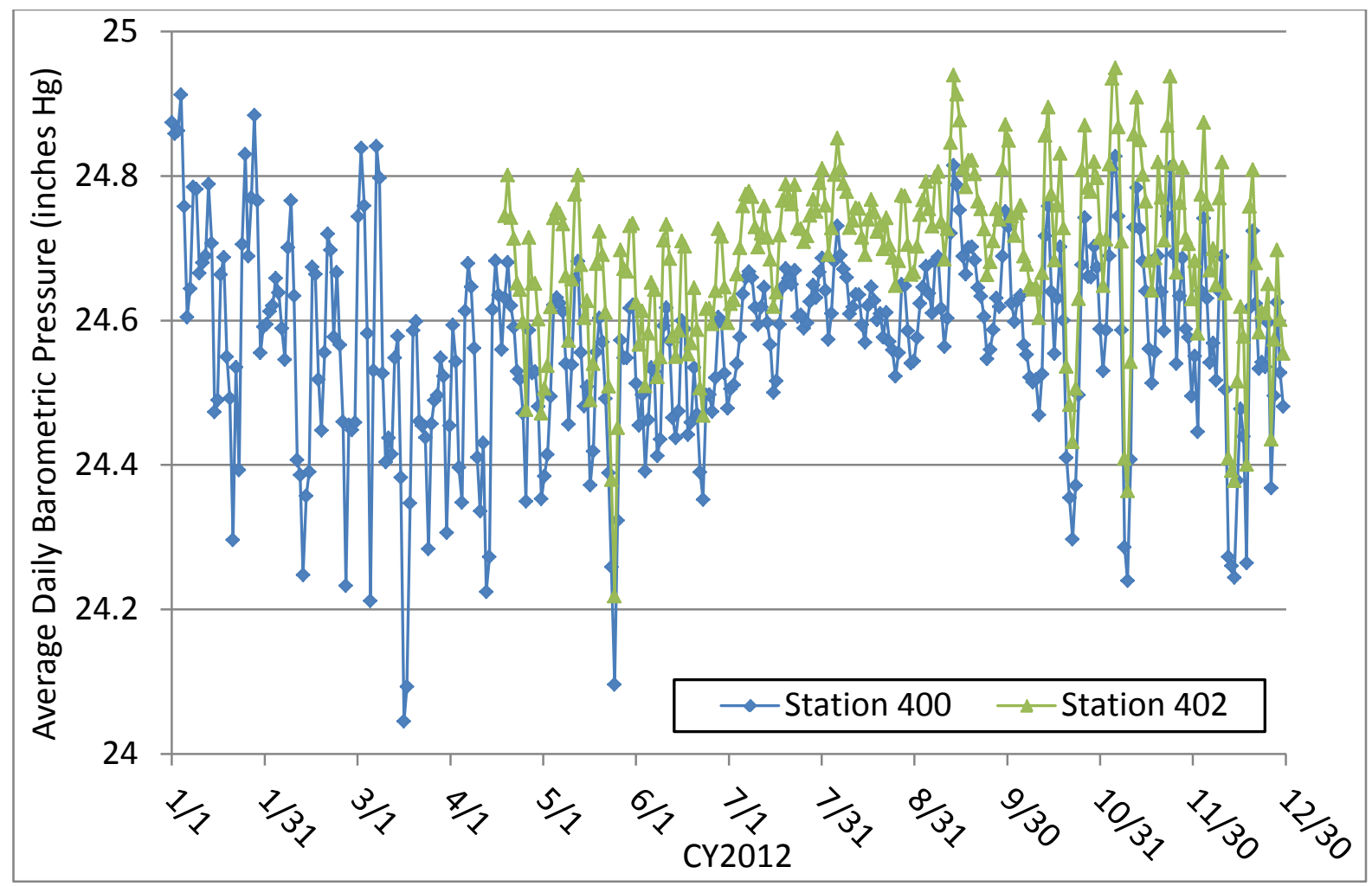

Figure A-9. Average daily barometric pressure at TTR air monitoring Stations 400, 401, and 402 during CY2012.

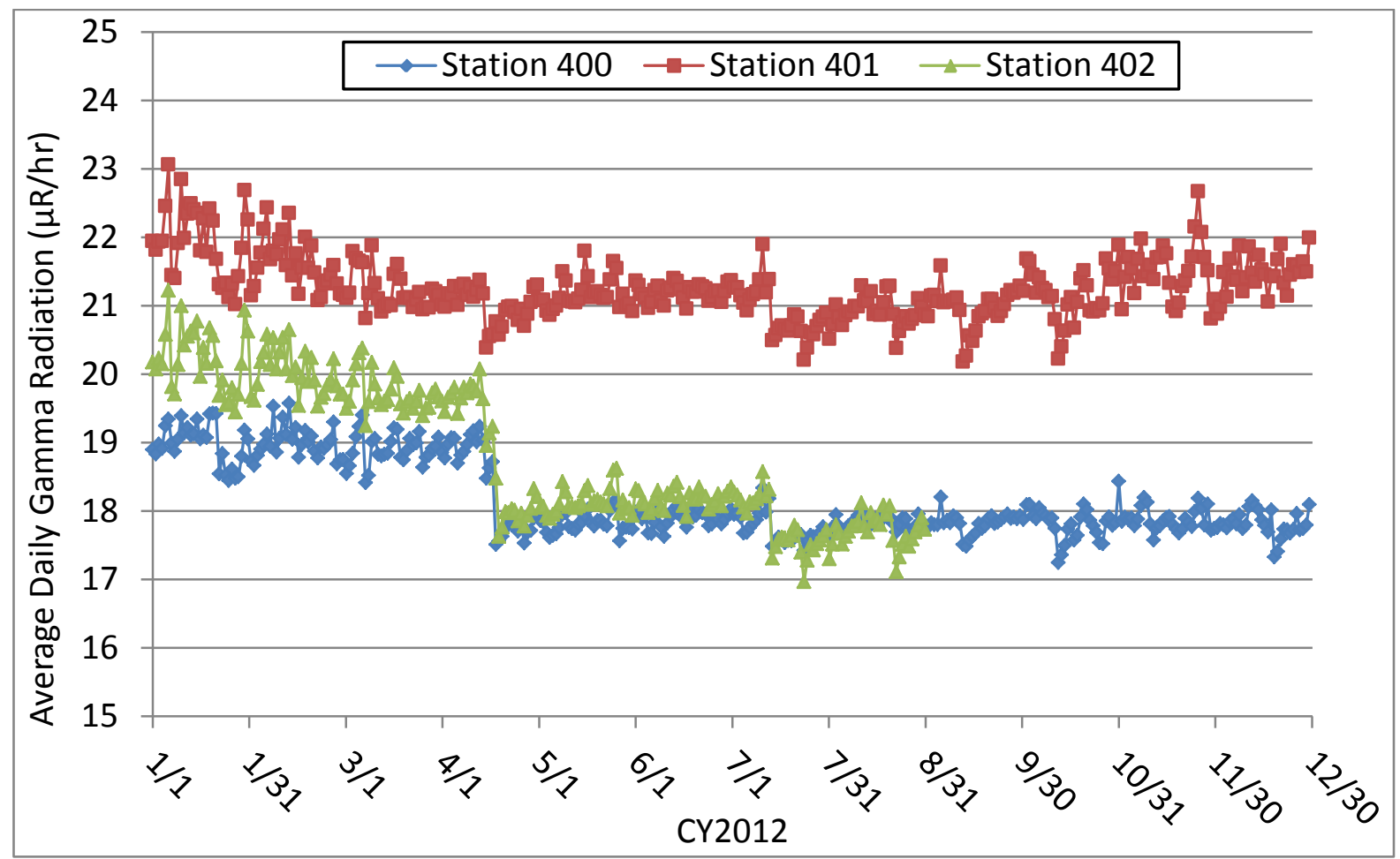

Figure A-10. Average daily gamma radiation at TTR air monitoring Stations 400, 401, and 402 during CY2012. 


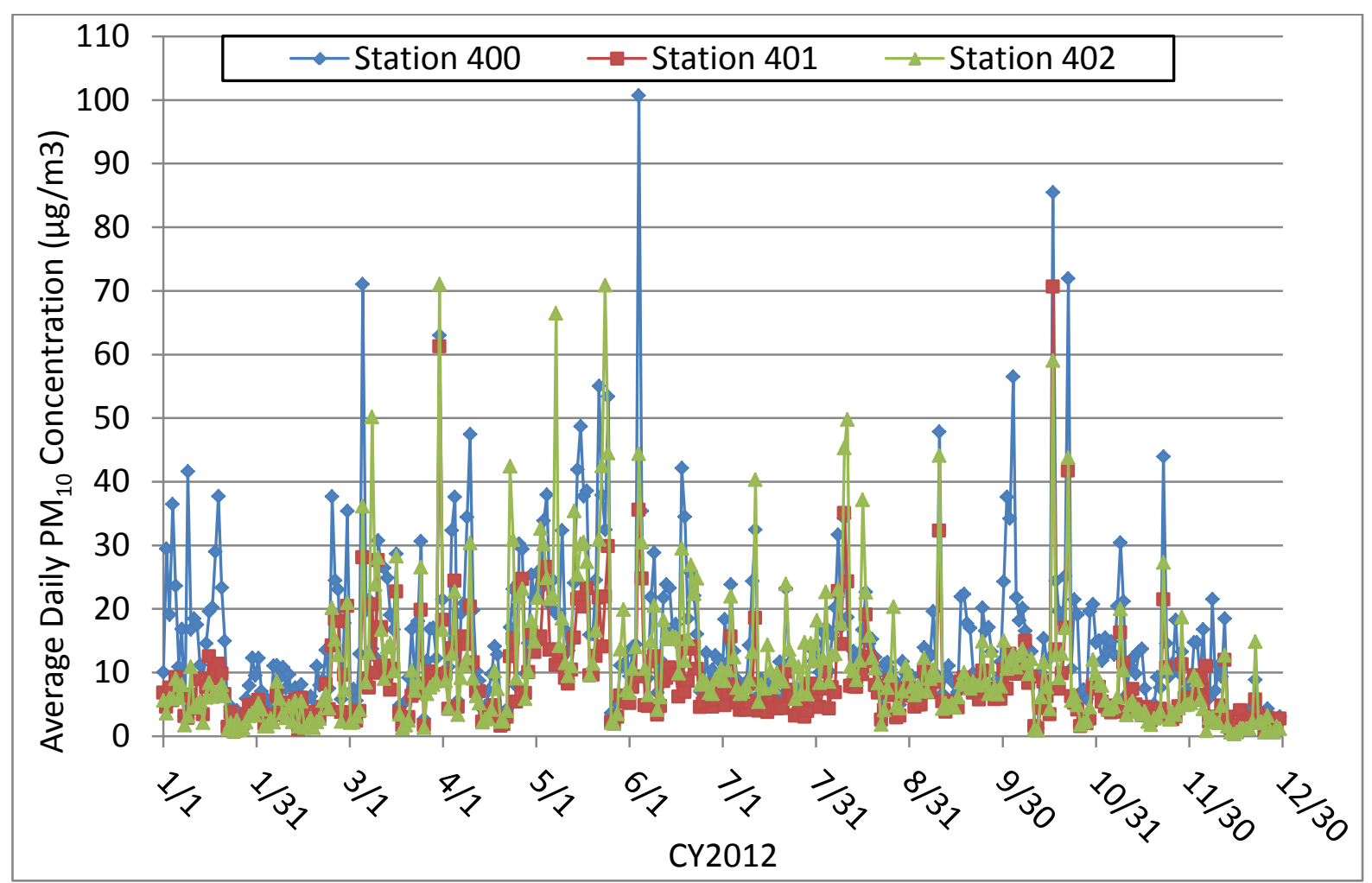

Figure A-11. Average daily PM10 concentration at the TTR air monitoring Stations 400, 401, and 402 duirng CY2012. 


\section{APPENDIX B: SALTATION REMOVED FROM THE DATA RECORD PRIOR TO ANALYSIS}

Table B-7. Saltation data excluded from analysis due to coincident precipitation at Station 401.

\begin{tabular}{|c|c|c|}
\hline Date & Total Perception (inches) & $\begin{array}{l}\text { Average Saltation Count } \\
\text { During Rain Periods } \\
\text { (Counts/10-min period) }\end{array}$ \\
\hline $01 / 21 / 12$ & 0.15 & 52.90 \\
\hline 03/17/12 & 0.12 & 23.70 \\
\hline $03 / 25 / 12$ & 0.05 & 9.75 \\
\hline 04/01/12 & 0.05 & 1.75 \\
\hline $04 / 11 / 12$ & 0.05 & 22.75 \\
\hline $04 / 26 / 12$ & 0.07 & 35.00 \\
\hline 05/26/12 & 0.20 & 5.15 \\
\hline $07 / 04 / 12$ & 0.06 & 0.17 \\
\hline $07 / 12 / 12$ & 0.07 & 8.20 \\
\hline 07/13/12 & 0.58 & 45.94 \\
\hline $07 / 22 / 12$ & 0.03 & 24.00 \\
\hline 07/23/12 & 0.77 & 15.46 \\
\hline 07/31/12 & 0.26 & 145.25 \\
\hline 08/11/12 & 0.02 & 68.00 \\
\hline 08/13/12 & 0.09 & 331.50 \\
\hline $08 / 14 / 12$ & 0.24 & 86.40 \\
\hline 08/20/12 & 0.32 & 6.44 \\
\hline 08/21/12 & 0.26 & 19.67 \\
\hline $08 / 22 / 12$ & 0.04 & 6.67 \\
\hline 08/29/12 & 0.12 & 86.67 \\
\hline 09/11/12 & 1.33 & 29.42 \\
\hline $10 / 10 / 12$ & 0.05 & 11.00 \\
\hline $10 / 11 / 12$ & 0.70 & 1.49 \\
\hline
\end{tabular}


Table B-8. Saltation data excluded from analysis due to coincident precipitation at Station 402.

\begin{tabular}{|c|c|c|}
\hline Date & Total Perception (inches) & $\begin{array}{l}\text { Average Saltation Count } \\
\text { During Rain Periods } \\
\text { (Counts/10min period) }\end{array}$ \\
\hline 01/21/12 & 0.07 & 70.14 \\
\hline $01 / 23 / 12$ & 0.02 & 0.00 \\
\hline 02/14/12 & 0.01 & 0.00 \\
\hline 02/28/12 & 0.03 & 0.00 \\
\hline 03/17/12 & 0.24 & 164.71 \\
\hline 03/19/12 & 0.05 & 0.00 \\
\hline 03/25/12 & 0.03 & 12.50 \\
\hline 03/26/12 & 0.06 & 0.00 \\
\hline 04/01/12 & 0.03 & 0.00 \\
\hline 04/11/12 & 0.03 & 46.00 \\
\hline 04/13/12 & 0.01 & 0.00 \\
\hline 04/26/12 & 0.01 & 13.00 \\
\hline 05/26/12 & 0.21 & 0.50 \\
\hline 07/04/12 & 0.03 & 0.00 \\
\hline $07 / 12 / 12$ & 0.08 & 3.00 \\
\hline 07/13/12 & 0.78 & 58.11 \\
\hline 07/22/12 & 0.04 & 91.00 \\
\hline 07/23/12 & 2.53 & 95.39 \\
\hline 07/31/12 & 0.21 & 721.67 \\
\hline 08/11/12 & 0.04 & 12.00 \\
\hline 08/12/12 & 0.01 & 6.00 \\
\hline 08/14/12 & 0.11 & 53.00 \\
\hline 08/18/12 & 0.1 & 41.00 \\
\hline 08/20/12 & 0.53 & 12.10 \\
\hline 08/21/12 & 0.19 & 7.43 \\
\hline 08/22/12 & 0.17 & 28.00 \\
\hline 09/11/12 & 0.86 & 17.33 \\
\hline 10/10/12 & 0.03 & 7.33 \\
\hline $10 / 11 / 12$ & 0.66 & 1.24 \\
\hline
\end{tabular}

